\title{
Labor Picketing and Commercial Speech: Free Enterprise Values in the Doctrine of Free Speech
}

Peaceful labor picketing, ${ }^{1}$ once treated as an exercise of freedom of speech, has been implicitly relegated by the Supreme Court to the status of an economic activity subject to extensive regulation. This doctrine should be seriously reexamined, particularly in light of more recent developments giving full First Amendment protection to peaceful non-labor picketing and substantial First Amendment protection to commercial advertising.

This Note argues that consumer picketing ${ }^{2}$ that does not coerce the listener $^{3}$ is expression entitled to First Amendment protection. ${ }^{4}$ In reaching

1. "Picketing" encompasses a broad range of activities, see Thornhill v. Alabama, 310 U.S. 88, 101 n.18 (1940), but is generally characterized by one or more persons walking or standing near a given locality while displaying a sign. For the purposes of this Note, "peaceful labor picketing" is defined as all such activity carried on by members or agents of a labor union in connection with a labor dispute, when unaccompanied by threats, harassment, violence, or other physically coercive conduct.

2. "Consumer picketing" takes place at consumer entrances only, and informs consumers of a strike or other labor dispute involving the employees of the picketed business or, in the case of secondary consumer picketing, see infra note 33 , of the business' suppliers or customers.

The First Amendment analysis advanced by this Note focuses on consumer picketing. Picketing directed toward employees and designed to induce a work stoppage raises two issues that do not arise in the case of consumer picketing. First, the union may be able to enforce economic sanctions against union members who cross picket lines, thus arguably introducing an element of coercion into even peaceful picketing. Second, the conduct the picket seeks to induce is sometimes a breach of contract and often less clearly legal than the consumer's decision not to patronize a picketed business. Whether and to what extent these factors alter the balance of First Amendment protection is beyond the scope of this Note.

3. Different courts and commentators use "coercion" to mean vastly different things. See infra notes 40-41. This Note adopts a conventional definition: consumer picketing is coercive rather than peaceful only if the picketers' conduct "overwhelms the will" of the consumers. See Jones, Picketing and Coercion: A Jurisprudence of Epithets, 39 VA. L. REV. 1023, 1028 (1953). This definition does not apply to picketing that is wholly peaceful but that nevertheless causes some timid consumers to shy away, or to otherwise peaceful picketing that involves "isolated incidents of abuse." See infra note 76.

4. Several commentators have seriously questioned the constitutionality of restrictions on consumer picketing. See, e.g., T. EMERSON, THE SYSTEM OF FREEDOM OF EXPRESSION 444-49 (1970) (consumer picketing, like non-labor picketing, should be fully protected); Mack \& Lieberwitz, Secondary 
this conclusion, the Note rejects both the argument that labor picketing is inherently coercive and the Court's recent suggestion that labor picketing does not concern a public issue. The Note maintains that the failure to extend constitutional protection to consumer picketing, when viewed together with the increased protection given commercial advertising, reveals substantive economic policy judgments made in the guise of First Amendment adjudication.

\section{Labor Picketing and Commercial Advertising: A Reordering of Con- stitutional Priorities}

In the early part of this century, beginning with Lochner v. New York, ${ }^{5}$ the Supreme Court elevated to constitutional status the common-law right of an employer to compete in the economic marketplace free from unjustified interference. ${ }^{6}$ Under the now discredited doctrine of "substantive due process," the Court struck down as unconstitutional economic and social legislation that interfered with this right. ${ }^{7}$ Lower federal and state courts, under Supreme Court guidance, routinely enjoined as tortious labor activity $^{8}$ that interfered with the employer's right of free enterprise.' In the

Consumer Picketing: The First Amendment Questions Remain, 32 MER(:ER L. REV. 815 (1981) (economic impact on business is arbitrary basis for constitutional adjudication); Note, Political Boycolt Activity and the First Amendment, 91 HARV. L. REV. 659, 682-83 (1978) (peaceful secondary consumer picketing, like non-labor political boycott, protected under First Amendment). None of these commentators considers the significance of developing First Amendment protection of commercial speech, or inquires into the economic values underlying these two doctrines.

5. Lochner v. New York, 198 U.S. 45 (1905) (state law prescribing maximum hours for bakery employees struck down as violation of due process).

6. Under the doctrine of tortious interference with business relations, see generally 86 C.J.S. Torts $\S 43$ (1954), which developed primarily as a judicial response to the growth of the labor movement, see generally Note, Tortious Interference with Contractual Relations in the Nineteenth Century: The Transformation of Property, Contract and Tort, 93 HARV. L. REV. 1510, 1529-37 (1980), labor activity that harmed a business was generally considered tortious, whereas harmful activity by competitors, often even in combination, was privileged. See id. at 1523-33.

7. Sec, e.g., Adkins v. Childrens Hosp., 261 U.S. 525 (1923) (minimum wage for women unconstitutional); Truax v. Corrigan, 257 U.S. 312 (1921) (statute prohibiting injunctions against peaceful picketing unconstitutional); Coppage v. Kansas, 236 U.S. 1 (1915) (state law prohibiting employers from requiring employees to sign contract promising not to join union ("yellow dog contract") unconstitutional); Adair v. United States, 208 U.S. 161 (1908) (federal law prohibiting railroad employers from requiring "yellow dog contracts" unconstitutional).

8. Sec, e.g., American Steel Foundries v. Tri-City Cent. Trades Council, 257 U.S. 184 (1921) (union limited to one picket); Hitchman Coal \& Coke Co. v. Mitchell, 245 U.S. 229 (1917) (union organizing of workers who had signed "yellow dog contracts" enjoined as interference with employer's constitutional right to run non-union business); Gompers v. Bucks Stove \& Range Co., 221 U.S. 418 (1911) (union's publicity of boycott enjoined); In re Debs, 158 U.S. 564 (1895) (strike enjoined as interference with business). See generally F. FRANKFURTER \& N. GREENE, THE LABOR INJUNCTION 1 (1930) (pervasive use of labor injunction known by labor movement and sympathizers as "government by injunction").

9. Substantive due process protected employers primarily from state action. But the constitutional protection accorded the employer's right of free enterprise was invoked to protect the employer from union action as well. First, the promotion of this common-law right to constitutional status was regarded as confirming the importance of the employer's right, thus strengthening support for injunc- 
mid-1930's, the Supreme Court began to repudiate its constitutional protection of business interests both from economic and social legislation ${ }^{10}$ and from labor activity. ${ }^{11}$ Current First Amendment doctrine concerning labor picketing and commercial advertising, however, has largely revived the Lochner era's hierarchy of protected values.

\section{A. Labor Picketing: The Rise and Fall of Thornhill}

Throughout the nineteenth century, peaceful picketing was regulated as a coercive economic activity. ${ }^{12}$ Although it acquired greater legitimacy as the labor movement gained power and public support, ${ }^{13}$ peaceful picketing

tions against union activity. See Hitchman Coal \& Coke Co. v. Mitchell, 245 U.S. 229, 251 (1917) (citing substantive due process cases in support of injunction against union). Second, a statute prohibiting injunctions against labor activity such as picketing was itself held to be state action violating the employer's constitutional right to be free of such interference. See Truax v. Corrigan, 257 U.S. 312 (1921).

10. See, e.g., West Coast Hotel Co. v. Parrish, 300 U.S. 379 (1937) (minimum wage constitutional; overruling Adkins v. Childrens Hosp., 261 U.S. 525 (1923)); Nebbia v. New York, 291 U.S. 502,537 (1934) (price regulation constitutional).

11. Senn v. Tile Layers Protective Union, 301 U.S. 468 (1937), effectively reversed Truax v. Corrigan, 257 U.S. 312 (1921). Although Senn held merely that a state anti-injunction act was not a taking of property in violation of the Fifth Amendment, the Court stated that "[m]embers of a union might, without special statutory authorization by a State, make known the facts of a labor dispute, for freedom of speech is guaranteed by the Federal Constitution." Id. at 478 . On the basis of this dictum, a few state courts extended First Amendment protection to peaceful picketing. See Denver Local 13 v. Perry Truck Lines, 106 Colo. 25, 101 P.2d 436 (1940). Others ignored it completely. See Roth v. Retail Clerks Local 1460, 216 Ind. 363, 24 N.E.2d 280 (1939).

12. In the nineteenth century, all picketing was treated as tortious. See Gregory, Constitutional Limitations on the Regulation of Union and Employer Conduct, 49 MICH. L. REV. 191, 198 (1950); supra note 6. Following the approach of then Judge Holmes in his dissent in Vegelahn v. Guntner, 167 Mass. 92, 104-09, 44 N.E. 1077, 1079-82 (1896), and in his article, Privilege, Malice, and Intent, 8 HARV. L. REV. 1 (1894), some courts began to accept, under certain circumstances, the economic interests of labor unions as a justification, like reasonable competition, for otherwise tortious interference. See F. FRANKFURTER \& N. GREENE, supra note 8, at 24-31. Even those courts that were comparatively reluctant to enjoin peaceful picketing balanced the economic interests of the union against those of the picketed business. See Goldfinger v. Feintuch, 276 N.Y. 281, 11 N.E.2d 910 (1937) (secondary consumer picketing directed only to product of primary employer justified by secondary employer's "unity of interest" with primary employer). Thus, peaceful picketing was, at best, treated as "a legitimate means of economic coercion," see F. FRANKFURTER \& N. GREENE, supra note 8 , at 31 , the legality of which depended on the economic objective of the union.

13. Congress first attempted to limit the use of injunctions against picketing and other labor activity in the Clayton Antitrust Act, $\S \S 6,20$, Pub. L. No. 212, 38 Stat. 731, 738 (1914) (codified as amended at 15 U.S.C. $\$ 17,29$ U.S.C. $\$ 52$ (1976)) (exempting labor from Sherman Antitrust Act and limiting federal court jurisdiction to issue labor injunctions). But these provisions of the Clayton Act were given a limited interpretation by the courts, which continued to issue labor injunctions. See A. Goldminn, The SUPREME COURT AND LABOR-MAN curbs on the federal courts were included in the Anti-Injunction (Norris-LaGuardia) Act, Pub. L. No. 65, 47 Stat. 70 (1932) (codified as amended at 29 U.S.C. $\$ \S 101-115$ (1976)). Several state legislatures also passed anti-injunction acts, modelled after the Norris-LaGuardia Act, which limited the jurisdiction of state courts to issue labor injunctions. See Smith \& DeLancey, The State Legislatures and Unionism, $38 \mathrm{MICH}$. L. REV. 987, 1013-20 (1940).

Unions began to fare better during this period in the courts as well as the legislatures. State courts that once treated all picketing as a prima facie tort began to recognize the union's economic objective of improving the wages and working conditions of its members as a legal justification under some circumstances for interference with business relations. See supra note 12. 
was still treated during the Lochner era as an exercise not of free speech but of economic power alone. With the demise of substantive due process, however, the Supreme Court extended First Amendment protection to organized labor activities that had previously been subject to injunctions. ${ }^{14}$

In Thornhill v. Alabama, the Court proclaimed that "the dissemination of information concerning the facts of a labor dispute must be regarded as within that area of free discussion that is guaranteed by the Constitution," 15 and struck down as unconstitutionally overbroad a state anti-picketing statute. ${ }^{16}$ The Court in Thornhill rejected any suggestion that picketing is not entitled to First Amendment protection because it may induce others to take action that harms the picketed business:

It may be that effective exercise of the means of advancing public knowledge may persuade some of those reached to refrain from entering into advantageous relations with the business establishment which is the scene of the dispute. Every expression of opinion on matters that are important has the potentiality of inducing action in the interests of one rather than another group in society. But the group in power at any moment may not impose penal sanctions on peaceful and truthful discussion of matters of public interest merely on a showing that others may thereby be persuaded to take action inconsistent with its interests. ${ }^{17}$

Although its holding was on the narrow ground of overbreadth, Thornhill established that restrictions on picketing were subject to the constraints of the First Amendment. ${ }^{18}$

14. See, e.g., Thomas v. Collins, 323 U.S. 516 (1945) (state may not, consistent with First Amendment, require union organizers to register before soliciting union membership); Hague v. CIO, 307 U.S. 496 (1939) (privileges and immunities clause of Fourteenth Amendment protects union circulars and mass meetings called by union organizers).

15. 310 U.S. 88,102 (1940).

16. Id. at 105. The overbreadth doctrine recognizes the danger that protected speech may be "chilled" by the very existence of statutes that sweep within their prohibition protected expression. Thus, a litigant may challenge such a statute on its face, even if the particular activity with which the litigant is charged is not constitutionally protected. See id. at 96-98; see also Gooding v. Wilson, 405 U.S. 518 (1972) (applying overbreadth analysis). See generally Note, The First Amendment Overbreadth Doctrine, 83 HARV. L. REV. 844 (1970).

17. 310 U.S. at 104. It is well established in First Amendment doctrine that constitutional protection extends beyond "abstract discussion" to speech that advocates action. See, e.g., NA $\Lambda$ CP v. Claiborne Hardware Co., 102 S. C. 3409, 3424 (1982) (boycott of white merchants); Organization for a Better Austin v. Keefe, 402 U.S. 415, 419 (1971) (leafleting to force real estate broker to stop "blockbusting"); NAACP v. Button, 371 U.S. 415, 429 (1963) (solicitation of legal clients); Thomas v. Collins, 323 U.S. 516, 537 (1945) (solicitation of union membership); Herndon v. Lowry, 301 U.S. 242, 259 (1940) (solicitation of Communist Party membership). Thus, speech generally may not be regulated merely because of the reaction of the listeners to its message. See infra pp. 951-52. This protection extends even to advocacy of illegal action, "except where such advocacy is directed to inciting or producing imminent lawless action and is likely to incite or produce such action." Brandenburg v. Ohio, 395 U.S. 444,447 (1969).

18. A decision that a statute is overbroad in violation of the First Amendment does not necessarily 
But those who greeted Thornhill with enthusiasm ${ }^{19}$ were soon disappointed..$^{20}$ Within ten years, the Court had adopted an extremely lenient standard of constitutionality for restrictions on labor picketing: ${ }^{21}$ any picketing having an "illegal objective" was not protected by the First Amendment. ${ }^{22}$ In its earliest formulation, this illegal objective test denied First Amendment protection to any picketing whose object and imminent effect was to force the picketed employer to violate an important state law. ${ }^{23}$ The doctrine was soon enlarged, however, and now includes any picketing aimed at pressuring the employer to do something that, while entirely legal, was judged by either the legislature or the enjoining court to be better

hold that the particular actor's conduct was privileged. See Note, supra note 16, at 845 . But the Court in Thornhill indicated that peaceful picketing itself was a protected means of communication. See 310 U.S. at 99. The protected status of peaceful picketing was made explicit in Carlson v. California, 310 U.S. 106, 112-13 (1940) (companion case to Thornhill).

Following Thornhill, several Supreme Court cases upheld and expanded the First Amendment right to picket. See, e.g., Cafeteria Employees Local 302 v. Angelos, 320 U.S. 293 (1943) (First Amendment right to picket not lost because of isolated incidents of abuse); Bakery Drivers Local 802 v. Wohl, 315 U.S. 769 (1942) (right to picket not lost merely because union picketed bakeries that supplied peddlers with whom union had immediate dispute); AFL y. Swing, 312 U.S. 321 (1941) (right to picket not lost merely because no immediate dispute between employer and employees).

19. See, e.g., Dodd, Picketing and Free Speech: A Dissent, 56 HARV. L. REv. 513 (1943); Jaffe, In Defense of the Supreme Court's Picketing Doctrine, 41 Mith. L. REv. 1037 (1943). But see Teller, Picketing and Free Speech, 56 HARV. L. REV. 180 (1942) (criticizing Thornhill).

20. Thornhill had little impact upon the state courts, in which most picketing cases were heard. Many continuied to uphold injunctions against picketing, either distinguishing or ignoring Thornhill. See Tanenhaus, Picketing-Free Speech: The Growth of the New Law of Picketing from 1940 to 1952, 38 CoRNELL. L.Q. 1 (1952) (Thornhill "was more dud than bombshell" in state courts).

21. Looking at Thornhill with the benefit of hindsight, one can discern a loophole that later cases expanded into a cavernous gap. The Court conceded that

the rights of employers and employees to conduct their economic affairs and to compete with others for a share in the products of industry are subject to modification or qualification in the interest of the society in which they exist. This is but an instance of the power of the State to set the limits of permissible contest open to industrial combatants.

310 U.S. at 103-04. This passage was cited frequently in later decisions limiting the right to picket, see, e.g., Carpenters \& Joiners Local 213 v. Ritter's Cafe, 315 U.S. 722,728 (1942). Those cases failed, however, to heed the caveat that directly followed that passage: "It does not follow that the State in dealing with the evils arising from industrial disputes may impair the effective exercise of the right to discuss freely industrial relations which are matters of public concern." 310 U.S. at 104.

22. The illegal objective doctrine was developed in the state courts partly in response to Thornhill. See Gregory, supra note 12 , at 201 . The doctrine was, however, only a slight refinement of the common-law analysis by which many state courts permitted extensive restrictions on picketing before Thornhill. See supra note 12 . Indeed, it appears that most state courts virtually ignored Thornhill and continued to enjoin peaceful picketing under much the same terms as before. See supra note 20.

23. See Giboney v. Empire Storage \& Ice Co., 336 U.S. 490 (1949). In Giboney, the union sought agreements from wholesale ice distributors not to sell ice to non-union ice peddlers. The Missouri court had held that such agreements violated the state anti-trade-restraint statute. Id. at 492-93. When Empire, a wholesale ice distributor, refused to sign such an agreement, the union peacefully picketed its place of business, reducing Empire's business by $85 \%$ when union truckdrivers refused to deliver goods to Empire.

It has been suggested that the illegal objective test as first announced in Giboney was closely patterned after the "clear and present danger" test then generally applied under the First Amendment, in that the Court seemed to require that the state interest be important, and that the threat of its violation be imminent. See Jones, The Right to Picket-Twilight Zone of the Constitution, 102 U. P^. L. REV. 995, 1021 (1954). 
left to the employer's free choice. ${ }^{24}$ Under the current illegal objective test, neither the importance of the state policy nor the means chosen to advance that policy are subjected to judicial scrutiny. ${ }^{25}$ The test has thus become circular and wholly deferential to legislative action..$^{26}$ The state, whose actions the First Amendment is intended to limit, is now free to establish the parameters of First Amendment protection for labor picketing. ${ }^{27}$

The First Amendment analysis of picketing in Thornhill focused upon the relationship between the union as speaker and its intended listeners-the workers or consumers to whom the union's message was directed. ${ }^{28}$ The illegal objective test, however, considers only the economic relationship between the union and the picketed business. ${ }^{29}$ The listeners-their right to be informed ${ }^{30}$ and their instrumental role in the effec-

24. See Hughes v. Superior Court, 339 U.S. 460 (1950). In Hughes, a Black citizens group picketed a store that refused to hire Blacks in proportion to their population in the area. An injunction was upheld by the Supreme Court on the basis of the state court's declaration that it was an illegal objective to seek hiring on the basis of race. In contrast to Giboney, the employer would not have violated any statute by acceding to the demands of the picketers and those who honored the picket. See also Teamsters Local 309 v. Hanke, 339 U.S. 470, 478-79 (1950) (illegal objective to pressure selfemployer to join union). In Hanke, the picketed employer was legally entitled to join the union, but the picketing had been enjoined on the basis of the state's "public policy" in favor of self-employment. Commentators sharply criticized these developments in the Court's picketing doctrine. See Fraenkel, Peaceful Picketing-Constitutionally Protected? 99 U. PA. L. REV. 1, 12 (1950) (illegal objective test undermines constitutional protection of peaceful picketing).

25. Compare Giboney v. Empire Storage \& Ice Co., 336 U.S. 490, 502 (1949) ("placards used as an essential and inseparable part of a grave offense against an important public law") with Teamsters Local 309 v. Hanke, 339 U.S. 470, 478 (1950) (decision to protect self-employers from picketing is "within the domain of a State's public policy").

26. Federal labor legislation, which preempts conflicting state law, see San Diego Bldg. Trades Council v. Garmon, 359 U.S. 236 (1959) (NLRB has exclusive jurisdiction over activities arguably protected or prohibited by NLRA); see also R. GORMAN, BASIC: TEXT ON LABOR LAW 766-86 (1976) (discussing labor law preemption doctrine), currently protects primary picketing in connection with a legal strike, see 29 U.S.C. $\S 157$ (1976). Under current doctrine, however, the First Amendment apparently poses no barrier to the removal of that protection.

27. This development was noted over 30 years ago:

We have travelled a long way. For a time it seemed as though peaceful picketing were going to receive real constitutional protection. Now it looks as though state courts, by the simple device of declaring union objectives contrary to public policy, can ban peaceful picketing in almost all situations where there is room for difference of opinion as to these objectives. We seem to be on the road back to government by injunction.

Fraenkel, supra note 24, at 12. See also Armstrong, Where Are We Going with Picketing? 36 CuLlF. L. REV. 1, 37 (1948) (only objectives that would create imminent danger of extremely serious social evil should be grounds for injunction under First Amendment).

28. See 310 U.S. at 101-05 (recognizing effect on listeners and listeners' interest in receiving information).

29. See, e.g., Teamsters Local 695 v. Vogt, 354 U.S. 284, 295 (1957) (picketing of self-employed person may be prohibited); Electric Workers v. NLRB, 341 U.S. 694 (1951) (picketing may be prohibited where picketed business merely sells struck employer's product).

30. Listeners' First Amendment rights have an uncertain status. Some cases suggest that there is an independent constitutional right to receive information or opinions. See, e.g., Board of Educ., Island Trees School Dist. v. Pico, 102 S. Ct. 2799, 2808 (1982) (plurality held First Amendment rights of listeners limit school board's power to remove books from school library); Kleindienst v. Mandel, 408 U.S. 753, 762-63 (1972) (First Amendment rights of listeners implicated when state excludes foreign speaker); Stanley v. Georgia, 394 U.S. 557, 564 (1969) (First Amendment protects private possession of obscene materials); Lamont v. Postmaster Gen., 381 U.S. 301 (1965) (domestic subscrib- 
tiveness of the picket ${ }^{31}$-have disappeared from the analysis completely. Under the illegal objective test, restrictions on picketing have been accorded the deference customarily granted to economic regulations. ${ }^{32}$

The First Amendment issues neglected by the Court's current analysis are most starkly posed by examining its discussion of the National Labor Relations Act (NLRA) prohibition on peaceful secondary consumer picketing $^{33}$ in NLRB v. Retail Store Employees, Local 1001 (Safeco). ${ }^{34}$ The Court in Safeco held that the union had violated the NLRA by peacefully picketing on the public sidewalk ${ }^{35}$ in front of the consumer entrances of the surety companies that sold insurance policies issued by Safeco, the struck employer. ${ }^{36}$ The pickets informed the public of the strike by Safeco employees; accompanying handbills, not proscribed by the NLRA, asked

ers constitutionally entitled to receive foreign publications). Other cases, while stressing the rights of listeners, seem to indicate that those rights are contingent upon the rights of the speaker. See, e.g., Virginia State Bd. of Pharmacy v. Virginia Citizens Consumer Council, 425 U.S. 748, 757 (1976) ("If there is a right to advertise, there is a reciprocal right to receive the advertising .....") In general, the rights of listeners are not explicitly considered, although such rights would seem implicit in the philosophical foundations of the First Amendment. See Emerson, Legal Foundations of the Right to Know, 1976 WAsll. U. L.Q. 1 (1976).

31. The listener must respond positively to the union's message in order for a peaceful, noncoercive picket to be effective. One must therefore ask whether it is possible for one person to coerce another by means of the voluntary action of an intervening person. See Jones, supra note 3, at 1047 . 49. The only possible affirmative answer, that picketing can be regulated because it starts the chain of coercion, see Gregory, Picketing and Coercion: $A$ Conclusion, 39 V $\Lambda$. L. REV, 1067, 1069 (1953), begs the question. An inducement to lawful action is generally protected by the First Amendment. See supra note 17.

32. Cf. N $\Lambda$ ACP v. Claiborne Hardware Co., 102 S. Ct. 3409, 3425-26 (1982) (characterizing labor picketing as subject to states' "broad power to regulate economic activity").

33. 29 U.S.C. $\S 158(\mathrm{~b})(4)(\mathrm{ii})(\mathrm{B})(1976)$. "Secondary consumer picketing" takes place at the consumer entrances of a business legally neutral in the labor dispute publicized by the picket. By contrast, primary picketing takes place at the site of the employer with which the union has a dispute. See generally R. GORMIN, supra note 26, at 257-61 (describing protected primary pickeling and prohibited secondary picketing). The secondary employer generally uses or sells the products or services of the primary employer. Because the primary employer often does not sell its products directly to the consumer, a secondary consumer picket is frequently the only direct way to reach the members of the public who use the primary employer's product.

34. 447 U.S. 607 (1980).

35. The union's picketing, like that in the other labor picketing cases, took place in what is regarded under the First Amendment as a "public forum": "Wherever the title of streets and parks may rest, they have immemorially been held in trust for the use of the public and, time out of mind, have been used for purposes of assembly, communicating thoughts between citizens, and discussing public questions." Hague v. CIO, 307 U.S. 496, 515 (1939), quoted in Carey v. Brown, 447 U.S. 455, 460 (1980). In general, the government violates the First Amendment when it prohibits picketing in a public forum based on the content of the picket's message. See infra pp. 951-52. Picketing on private property, however-even in a shopping center, which might be regarded as the modern functional equivalent of a public forum-is not protected by the First Amendment. See Hudgens v. NLRB, 424 U.S. 507 (1976). But see Food Employees Local 590 v. Logan Valley Plaza, Inc., 391 U.S. 308 (1968) (overruled by Hudgens) (labor picketing otherwise legal may not be prohibited solely because it takes place on private property that serves function of public forum). Cf. Pruneyard Shopping Center v. Robins, 447 U.S. 74 (1980) (federal constitution not violated by statc constitutional provision protecting speech in private shopping center).

36. 447 U.S. at $609-10$. 
consumers to cancel their Safeco policies. ${ }^{37}$ Because the surety companies were dependent for ninety percent of their business on the sale of Safeco policies, the picketing was held to have the illegal objective ${ }^{38}$ of coercing the "neutral" employer. ${ }^{39}$

Although the Court in Safeco appeared to be concerned only with the economic coercion of the picketed business that may result from consumers' response to the picket, ${ }^{40}$ its application of the illegal objective test may

\section{Id. at 610 n.3.}

38. Id. at 609 . The extent to which the surety companies could be affected by the picketing enabled the Court to distinguish its decision in NLRB v. Fruit \& Vegetable Packers Local 760 (Tree Fruits), 377 U.S. 58 (1964) (construing NLRA to permit peaceful consumer picketing at secondary site if aimed only at primary product). In Tree Fruits, the picketing was expressly limited to the Washington State apples sold by the secondary employer, Safeway grocery stores. The apples constituted a tiny portion of Safeway's business. If the union was entirely successful in accomplishing its purpose, the reduction of sales of Washington apples, Safeway would not be "coerced," but might "drop the item as poor seller." Id. at 72-73. The Court cited "concern that a broad ban against peaceful picketing might collide with the guarantees of the First Amendment," id. at 63, in support of its narrow reading of NLRA $\S 8(\mathrm{~b})(4)(\mathrm{ii})(B)$. Three members of the Court-Black, Harlan, and Stewart-found the Court's construction and reading of legislative history unconvincing. Commentators generally agreed with them that Congress had intended to prohibit all consumer picketing at secondary sites. See The Supreme Court, 1963 Term, 78 HARV. L. RkV. 143, 290-291 (1964) (Justice Brennan's opinion "required disregarding the remarks of key opponents of the bill and construing the statements of key supporters both narrowly and technically").

39. 447 U.S. at 616 . Although the picketed surety companies were "neutral" as defined by the NLRA, id. at 610, Safeco owned substantial amounts of stock-up to $53 \%$-in each company, and Safeco representatives sat on each company's board of directors. Retail Store Employees Local 1001, 226 N.L.R.B. 754, 755 (1976). Furthermore, the fact that the picketed companies were wholly dependent on Safeco for their business suggests that the companies were not neutral, in the common sense of the word, in the dispute between Safeco and its employees. Indeed, it has been suggested that prohibiting picketing in the Safeco situation while allowing it in the Tree Fruits situation, see supra note 38, "creates the odd result that the more neutral a party seems the more likely it is to become involved in another party's labor dispute." Case Comment, Consumer Picketing of Economically Interdependent Parties: Retail Store Employees Local 1001 v. NLRB (Safeco Title Insurance Co.), 32 STAN. L. REV. 631,637 (1980).

One might argue, in support of allowing secondary consumer picketing, that to the extent an employer ties the success of its own business to the fortunes of a certain supplier or manufacturer, that employer has a "unity of interest" with the manufacturer, cf. Goldfinger v. Feintuch, 276 N.Y. 281, 11 N.E.2d 910 (1937) (striking down injunction against secondary picketing on ground of "unity of interest"), and "assumes the risks . . that follow when labor conflict embroils the manufacturer . . . " Safeco, 447 U.S. at 623 (Brennan, J., dissenting). These arguments are, of course, issues of policy and statutory construction unrelated to the constitutional issue analyzed here.

40. 447 U.S. at 616. The Court has long been concerned with the "coercive" economic effect of picketing. Compare Bakery Drivers Local 609 v. Wohl, 315 U.S. 769, 773 (1942) (no significant loss of business; picketing protected) with Carpenters \& Joiners Local 213 v. Ritter's Cafe, 315 U.S. 722 , 724 (1942) (business cut by 60\%; picketing unprotected) and Giboney v. Empire Storage \& Ice Co., 336 U.S. 490, 493 (1949) (business cut by 85\%; picketing unprotected). Eventually, the Court dropped this inquiry into the actual effect of the picket; the intended effect-the result, that is, if all listeners were successfully persuaded by the picket's information and appeal-was sufficient in Safeco to establish illegality.

Yet the economic effect, actual or intended, of a peaceful consumer picket has no bearing on whether it is communication and should not be relevant in determining its level of protection under the First Amendment. See infra p. 952. The Thornhill Court appeared to embrace this position. 310 U.S. 88, 104 (1940) (picketing may not be prohibited merely because information may lead others to withhold patronage or labor). Later cases, however, suggest that labor picketing that has an economic impact the State wishes to avoid is for that reason something other than communication. In Teamsters Local 695 v. Vogt, 354 U.S. 284, 289-93 (1957), the Court reviewed its labor picketing decisions since 
have been based on an implicit assumption that such a picket always coerces the consumers themselves. ${ }^{41}$ Yet there was no suggestion that the consumers in Safeco were in any way threatened, harassed, or even persuaded to honor the pickets' appeal. Not a single link in the chain of events the union hoped to set in motion-consumers cancelling their Safeco policies, the surety companies pressuring Safeco to settle the strike, Safeco consequently settling on terms more favorable to the union-was itself illegal. ${ }^{42}$ Furthermore, it may only have been at the site of the "neutral" employer that the union could communicate effectively with the consumers of the primary product. Nevertheless, the First Amendment challenge to the validity of this section of the NLRA, squarely faced for the first time in $S a f e c o,{ }^{43}$ was disposed of in a few terse sentences about the union's illegal objective of coercing the secondary "neutral" employer. ${ }^{44}$

1921. Noting, for instance, that the picketed business in Carpenters \& Joiners Lucal 213 v. Ritter's Cafe, 315 U.S. 722 (1942), which suffered substantial economic loss as a result of the peaceful picketing, was legally neutral in the dispute, the Court concluded that such picketing "involved little, if any "communication." " 354 U.S. 284, 290 (1957).

41. See 447 U.S. at 618-19 (Stevens, J., concurring); infra p. 953. In the Safeco case itself, picketing outside the entrance could not coerce consumers to cancel their Safeco policies inside the building. But in other cases of secondary consumer picketing, the consumer could be coerced as well as persuaded to withdraw her patronage by, for instance, simply not entering a picketed store.

The suggestion that picketing may coerce the listeners had appeared already in Bakery Drivers Local 802 v. Wohl, 315 U.S. 769 (1941):

Picketing by an organized group is more than free speech, since it involves patrol of a particular locality and since the very presence of a picket line may induce action of one kind or another, quite irrespective of the nature of the ideas which are being disseminated. Hence those aspects of picketing make it the subject of restrictive regulation.

Id. at 776-77 (Douglas, J. concurring). Douglas was careful to distinguish between conduct that may coerce the listeners and the economic "coercion" or pressure on the picketed business that may result from persuasion of the listeners. Consistent with Thornhill, he denied that the latter form of "coercion" was sufficient to justify restrictions on peaceful picketing. Id. Later cases, however, have manifestly confused the possibility, noted by Douglas, that picketing may induce a response independent of its message with the effect that a response based on that message may have on the picketed business. See Teamsters Local 695 v. Vogt, 354 U.S. 284, 289-90 (1957) (denying communicative nature of picket against "neutral" party).

Many commentators have focused on the question of coercion in analyzing the First Amendment status of picketing. See, e.g., Cox, The Infuence of Mr. Justice Murphy on Labor Law, 48 MicH. L. REV. 767, 774-82, 787-93 (1950) (Court should distinguish between "signal picketing," which relies for its impact on extrinsic economic sanctions against listeners, and "publicity picketing," which relies on message); Gregory, supra note 12, at 198 (all picketing coerces business); Jones, supra note 3, at 1050-52 (picketing is not coercion but communication that may cause economic loss for picketed business).

42. A. CoX, FREEUOM OH EXPRESSION 44-45 (1980).

43. The question was expressly avoided in NLRB v. Fruit \& Vegetable Packers Local 760,377 U.S. 58, 63 (1964). See supra note 38.

44. The entire constitutional analysis in Safeco reads as follows:

The Court of Appeals suggested that application of $\S 8(\mathrm{~b})(4)(\mathrm{ii})(\mathrm{B})$ to the picketing in this case might violate the First Amendment. We think not. Although the Court recognized in Tree Fruits that the Constitution might not permit "a broad ban against peaceful picketing," the Court left no doubt that Congress may prohibit secondary picketing calculated "to persuade the customers of the secondary employer to cease trading with him in order to force him to cease dealing with, or to put pressure upon, the primary employer." Such picketing spreads labor discord by coercing a neutral party to join the fray. . . . [T] 
It is thus evident from Safeco and previous decisions establishing the illegal objective doctrine that the First Amendment is no longer a serious hurdle to restrictions on labor picketing. Without overruling or even mentioning Thornhill, the Court has treated labor picketing, even when unaccompanied by coercive conduct, as a purely economic activity.

\section{B. Non-Labor Picketing: The Emergence of the Public Issue/Labor Distinction}

In the past twenty years, non-labor picketing has received full First Amendment protection from content-based restrictions. ${ }^{45}$ Until very recently, however, it was not altogether clear whether this protection would extend to picketing in support of an economic boycott. ${ }^{46} \mathrm{~A}$ unanimous Court supplied the answer in NAACP v. Claiborne Hardware Co. ${ }^{47}$ ruling that peaceful picketing by civil rights groups in support of a boycott of white merchants was fully protected by the First Amendment, and could not be the basis for tort liability..$^{48}$ That decision was a ringing confirma-

held that a prohibition on "picketing in furtherance of [such] unlawful objectives" did not offend the First Amendment. We perceive no reason to depart from that well-established understanding. As applied to picketing that predictably encourages consumers to boycott a secondary business, $\S 8(\mathrm{~b})(4)(\mathrm{ii})(\mathrm{B})$ imposes no impermissible restrictions upon constitutionally protected speech.

447 U.S. at 616 (citations omitted).

45. Sce, e.g., Carey v. Brown, 447 U.S. 455, 466-67 (1980) (ordinance prohibiting all but labor picketing unconstitutional); Police Dep't v. Mosley, 408 U.S. 92, 95-96 (1972) (anti-picketing ordinance with labor exception violates equal protection clause and First Amendment); Shuttlesworth v. Birmingham, 394 U.S. 147, 155 (1969) (ordinance requiring license to march or picket violates First Amendment); Edwards v. South Carolina, 372 U.S. 229, 235 (1963) (peaceful mass picketing is exercise of basic First Amendment right). See generally Karst, Equality as a Central Principle in the First Amendment, 43 U. CHI. L. REV. 20, 29-35 (1975) (importance of content neutrality to First Amendment doctrine).

46. One early Supreme Court case, Hughes v. Superior Court, 339 U.S. 460 (1950), suggested that non-labor picketing in support of an economic boycott, in this case by a Black citizens group demanding proportional hiring, would be treated no differently than labor picketing and would be subject to the deferential illegal objective test. But later cases involving civil rights picketing established a higher level of protection that has been applied by the Fifth Circuit in cases involving economic boycotts. See, e.g., Henry v. First Nat'l Bank, 595 F.2d 291 (5th Cir. 1979) (enjoining on First Amendment grounds broad state court injunction against all picketing in support of civil rights boycoit); Machesky v. Bizzell, 414 F.2d 283 (5th Cir. 1969) (injunction against all activity in support of civil rights boycott, including peaceful picketing, overbroad in violation of First Amendment); Kelly v. Page, 335 F.2d 114 (5th Cir. 1964) (peaceful civil rights picketing in support of boycott protected by First Amendment). Cf. State of Missouri v. National Org. of Women, 620 F.2d 1301 (8th Cir. 1980) (NOW's boycott of state businesses to achieve passage of Equal Rights Amendment protected under First Amendment and not proscribed by Sherman Act). See generally Note, supra note 4 (peaceful activity, including picketing, in support of politically motivated economic boycott should be protected by First Amendment).

47. 102 S. Ct. 3409 (1982).

48. The decision represents the culmination of more than 12 years of litigation over the boycott. Id. at 3413-14. The aims of the boycott were both "primary"-urging merchants to employ black clerks and cashiers-and "secondary"-putting pressure on the merchants to influence political decisions. Id. at 3418. The means used in support of the boycott were primarily peaceful, including marches, pickets, and speeches, id. at 3420, but several violent incidents occurred, id. at 3421-22. 
tion that non-labor picketing, unlike labor picketing, is subject only to reasonable content-neutral restrictions, ${ }^{49}$ and is otherwise fully protected as an exercise of free speech.

The Court distinguished cases upholding restrictions on secondary boycotts and picketing by labor unions as involving "Congress' striking of the delicate balance between union freedom of expression and the ability of neutral employers, employees, and consumers to remain free from coerced participation in industrial strife." ${ }^{30}$ The NAAGP boycott, in contrast, involved "expression on public issues [, which] has always rested on the highest rung of the hierarchy of First Amendment values."

The distinction between "public issue" picketing and labor picketing was first articulated in Carey v. Brown, ${ }^{52}$ decided on the same day as Safeco. Carey struck down a residential picketing ordinance that prohibited all but labor picketing as a violation of the equal protection clause and the First Amendment because it discriminated between messages on the basis of their content..$^{53}$ This same content-based distinction has now

The state trial court held 130 individual defendants and the national NAACP liable for over $\$ 1.25$ million in damages. Id. at 3414-16. The Mississippi Supreme Court reversed portions of the judgment and remanded for reduction of damages, id. at 3416-17, but upheld the imposition of liability for most defendants, including the NA $\mathrm{NCP}$, on the theory that all defendants had agreed to use force, violence, and threats in support of the boycott, and that the entire boycott was therefore illegal. Id. at 3416 .

The Supreme Court unanimously reversed, holding all peaceful activity in support of the boycott, including threats of social ostracism and other "coercive" social pressure, to be protected by the First Amendment. Id. at 3427 . Only losses clearly shown to be a proximate result of unlawful conduct could be recovered. Id. at 3429 .

49. See, e.g., Grayned v. City of Rockford, 408 U.S. 104 (1972) (statute prohibiting noisy and disruptive demonstrations near school valid); Cameron v. Johnson, 390 U.S. 611 (1968) (law that prohibits pickets from obstructing doors to courthouse valid); see also Smith v. Grady, 411 F.2d 181 (5th Cir. 1969) (injunction restricting number and conduct of pickets reasonable under circumstances, except for requirement of silence).

50. 102 S. Ct. at 3425-26 (quoting NLRB v. Retail Store Employees Local 1001, 447 U.S. 607, 617-18 (1980) (Blackman, J., concurring)). The Court elaborated no further on how this deference to congressional policy could be justified under the First Amendment.

51. 102 S. Ct. at 3426 (quoting Carey v. Brown, 447 U.S. 455, 467 (1980)). Although "a major purpose of the boycott was to influence governmental action," $102 \mathrm{~S}$. Ct. at 3426 , the Court does not rely wholly on this fact in characterizing the boycott as concerning public issues. Many cases cited in support of the First Amendment analysis do not concern attempts to influence government action, but reflect a broader conception of "public issues." See, e.g., id. at 3424 (citing Thornhill v. Alabama, 310 U.S. 88 (1940) and Organization for a Better Austin v. Keefe, 402 U.S. 415 (1971) (attempt to persuade real estate broker to stop "blockbusting" tactics)); id. at 3425 (citing Thomas v. Collins, 323 U.S. 516 (1945) (soliciting union membership)). The Court also referred explicitly to dissatisfaction with business policy and to economic change. Id. at 3424-26, 3429, 3237. This broader definition of "public issue" is more consistent with First Amendment doctrine than a definition restricted to clectoral politics. See infra note 92.

52. 447 U.S. 455 (1980).

53. Id. at 471. The statute in Carey was subjected to strict scrutiny under the equal protection clause because it impinged on the fundamental First Amendment right of freedom of speech on the basis of a classification. Id. at 460-63. Because discrimination on the basis of content is strictly scrutinized under the First Amendment itself, see Consolidated Edison Co. v. Public Serv. Comm'n, 447 U.S. 530,540 (1980), precisely the same test would have been applied even without the invocation of the equal protection clause.

The Court introduced the public issue/labor picketing distinction in the following passage: 
been fully incorporated into the Supreme Court's own doctrine: labor picketing is not considered "public issue picketing" and, on the basis of its content, may be regulated much more freely.

\section{Commercial Speech: First Amendment Protection of Economic Competition}

The constitutional status of commercial advertising has risen as that of labor picketing has declined. Shortly after Thornhill, the Court declared in Valentine v. Chrestensen ${ }^{54}$ that the First Amendment "poses no . . . restraint on government as respects purely commercial advertising." ${ }^{35}$ The right to advertise was regarded as coextensive with the right to pursue a gainful occupation, ${ }^{56}$ and, in accordance with the Court's newly-learned deference in matters of economic and social policy, ${ }^{57}$ within the legislature's regulatory prerogative. ${ }^{58}$ In the last decade, however, the Court has rejected the doctrine announced in Valentine and extended substantial First Amendment protection to advertising, ${ }^{59}$ although the precise constitutional standard to be applied in commercial speech cases was clarified only recently.

On the same day that it first articulated the distinction between labor and "public issue" picketing in Carey, and illustrated its devastating consequences for consumer picketing by labor unions in Safeco, the Court announced, in Central Hudson Gas \& Electric v. Public Service Commis-

The central difficulty [with the state's argument that labor protests merit special protection] is that it forthrightly presupposes that labor picketing is more deserving of First Amendment protection than are public protests over other issues, particularly the important economic, social, and political subjects about which these appellees wish to demonstrate. We reject that proposition. Cf. T. Emerson, The System of Freedom of Expression 444-449 (1970) (suggesting that non-labor picketing is more akin to pure expression than labor picketing and thus should be subject to fewer restrictions).

447 U.S. at 466 . Though making this distinction, Emerson argues for full protection of consumer picketing like that in NLRB v. Fruit \& Vegetable Packers Local 760, 377 U.S. 58 (1964). See T. EMERSON, supra note 7, at 444-49. NLRB v. Retail Store Employees Local 1001 flies in the face of Emerson's analysis.

54. 316 U.S. 52 (1942).

55. Id. at 54. Accord Breard v. Alexandria, 341 U.S. 622 (1951).

56. 316 U.S. at 54.

57. See supra p. 940 .

58. 316 U.S. at 54.

59. See, e.g., Virginia State Bd. of Pharmacy v. Virginia Citizens Consumer Council, 425 U.S. 748 (1976) (ban on price advertising by pharmacists violates First Amendment); Bigelow v. Virginia, 421 U.S. 809 (1975) (ban on advertising of abortion referral service violates First Amendment). For scholarly commentary on the developing First Amendment protection of commercial speech, see Baker, Commercial Speech: A Problem in the Theory of Freedom, 62 IOWA L. REV. 1 (1976) (commercial speech should not be protected by First Amendment); Farber, Commercial Speech and First Amendment Theory, 74 Nw. U.L. REV. 372 (1979) (Court has applied lower standard where state interest related to contractual rather than informational aspect of advertising); Jackson \& Jeffries, Commercial Speech: Economic Due Process and the First Amendment, 65 V^. L. REV. 1 (1979) (protection of commercial speech reminiscent of Lochner). 
sion, ${ }^{60}$ the constitutional standard by which restrictions on commercial advertising would be judged. Because commercial advertising is regarded as a particularly hardy form of speech, not easily "chilled,"61 limited regulation of its content remains permissible. Regulation of deceptive advertising or advertising related to an illegal commercial activity thus does not offend the First Amendment. ${ }^{62}$ But truthful advertising of legal commercial activity may be regulated only if the regulation is no broader than necessary to promote directly a substantial state interest. ${ }^{63}$ In a decision notable for its detailed scrutiny of legislative ends and means, the Court applied this test and struck down as unnecessarily broad a ban on purely promotional advertising by a public utility, even though the ban was found to promote directly the state's substantial interest in encouraging conservation of energy. ${ }^{64}$

This analysis affords substantial First Amendment protection to economic competition through advertising. Only the uncertain difference between "substantial" and "compelling" now distinguishes the First Amendment standard for most commercial advertising from the First Amendment standard for explicitly political speech. ${ }^{65}$ Central Hudson, together with Safeco, thus heralded the reversal of the constitutional priorities established in Thornhill and Valentine: commercial advertising, although not fully protected, is more protected than peaceful labor picketing. ${ }^{66}$

\section{First Amendment Protection for Consumer Picketing: Restoring Constitutional Priorities}

Despite the Court's decision in Safeco and the public issue/labor distinction made in Claiborne Hardware and Carey, the premises of Thorn-

60. 447 U.S. 557 (1980).

61. Id. at 564 n.6.

62. Id. at 563-64. See Friedman v. Rogers, 440 U.S. 1, 13, 15-16 (1979) (advertising more likely to mislead than inform is unprotected); Pittsburgh Press Co. v. Pittsburgh Comm'n on Human Relations, 413 U.S. 376, 388 (1973) (sex-segregated "help wanted" ads are related to sex discrimination in employment and may be prohibited).

This latter exception is not analogous to the illegal objective test applied to labor picketing. Under that test, the ban struck down in Central Hudson would presumably have been upheld because the state had declared the promotion of energy consumption by means of advertising to be against public policy. Cf. supra pp. 943-44 (circularity of illegal objective test).

63. 447 U.S. at 566.

64. Id. at 568-69.

65. See id. at 591 (Rehnquist, J., dissenting). Indeed, it is not clear that there is any difference between a "compelling" and a "substantial" state interest. See United States v. O'Brien, 391 U.S. 367, 376-77 (1968) ("To characterize the quality of the government interest which must appear, the Court has employed a variety of descriptive terms: compelling; substantial . . . .")

66. The Central Hudson test explicitly weighs both the importance of the government interest, 447 U.S. at 568-69, and the tightness of "fit" between means and ends, id. at 570-71. Neither inquiry is performed under the illegal objective test. See supra p. 943. 
hill remain valid: peaceful labor picketing continues to be an important means of communication concerning matters of public concern. Restrictions on labor picketing therefore should be subject to strict First Amendment scrutiny.

\section{A. Labor Picketing as a Means of Communication}

Since peaceful consumer picketing entails communication, ${ }^{67}$ its regulation by government should be subjected to a careful First Amendment analysis. ${ }^{68}$ Under current Supreme Court doctrine, any regulation of expressive activity based either directly on the content of the message communicated by the activity, or on the possible reaction of the listeners to that content, ${ }^{69}$ is subject to rigorous scrutiny. The regulation may stand only if the speech falls into one of the narrow categories of unprotected speech, ${ }^{70}$ or if the regulation is a narrowly drawn means of achieving a

67. Although the Court has applied the deferential illegal objective test, which affords no more than due process protection to labor picketing, it continues to acknowledge that labor picketing does involve a significant element of communication. See NAACP v. Clairborne Hardware Co., 102 S. Ct. 3409,3425 (1982).

68. See United States v. O'Brien, 391 U.S. 367, 376-77 (1968). O'Brien was convicted for burning his draft registration card. Although the Court upheld his conviction, it took O'Brien's First Amendment claim seriously enough to articulate a four-part test under which such claims of communicative intent could be judged. See id. at 376-77. The claim that labor picketing is protected expression should hardly be given less scrutiny than O'Brien's claim.

The analysis put forward in this section draws heavily upon that advanced by John Hart Ely as exemplified in his article, Flag Desecration: $A$ Case Study in the Roles of Categorization and Balancing, 88 HARV. L. REV. 1482 (1975). Ely attempts to articulate the theory behind recent Supreme Court cases involving expression mixed with action or symbolic speech. Those cases include Cohen v. California, 403 U.S. 15 (1971) (conviction for wearing jacket with slogan "Fuck the Draft" violates First Amendment); Tinker v. Des Moines Indep. Community School Dist., 393 U.S. 503 (1969) (suspension of students for wearing black armbands in war protest violates First Amendment); United States v. O'Brien, 391 U.S. 367 (1968) (conviction for draft card burning not barred by First Amendment). Ely finds the key to the Court's seemingly divergent decisions in $O$ 'Brien's requirement that the government interest asserted in support of regulation of such activity must be unrelated to the suppression of free expression. See 391 U.S. at 367-77. Thus, if the government interest remains even if no message is received by the listeners, the relatively deferential $O O^{\prime} B r i e n$ test applies. But if the government interest is related to the content of the message and the listeners' possible reaction to that message, a much stricter level of scrutiny applies. Ely, supra, at 1496-98. This distinction between content-based and content-neutral regulations of expressive activity has become much more explicit in more recent cases such as Carey v. Brown, 447 U.S. 455 (1980), and Police Dept. v. Mosley, 408 U.S. 92 (1972).

69. "If the First Amendment means anything, it means that, absent clear and present danger, government has no power to restrict expression because of the effect its message is likely to have on the public." Central Hudson Gas \& Elec. Co. v. Public Serv. Comm'n, 447 U.S. 557, 575 (1980) (Blackmun, J., concurring). See also Virginia State Bd. of Pharmacy v. Virginia Citizens Consumer Council, 425 U.S. 748, 769-70 (1976) (First Amendment violated by ban on price advertising motivated by consumers' expected reaction to information); Cohen v. California, 403 U.S. 15, 23-24 (1971) (state may not punish wearing of slogan "Fuck the Draft" based on fear of audience reaction); Tinker v. Des Moines School Dist., 393 U.S. 503, 508-09 (1969) (school may not prohibit black armbands based on fear of disruption, or controversy caused by message); cases cited at supra note 17. See generally Ely, supra note 68, at 1496-1502.

70. Courts can determine whether a species of speech is within the scope of the First Amendment only by examining its content. Speech falling into one of several narrow categories is subject to whole- 
compelling state interest. ${ }^{71}$ If the regulation is unrelated to content, it will stand unless the incidental restriction of freedom of expression is greater than necessary to advance the state's interest. ${ }^{72}$

The illegal objective test, under which all labor picketing can be extensively regulated, is apparently based not on the picket's message, but on the assumption that it is inherently coercive. ${ }^{73}$ This assumption has been made without drawing the crucial distinction between the economic coercion of the picketed business that may result if the listeners are persuaded by the message, ${ }^{74}$ and the coercion of the listeners themselves. ${ }^{75} \mathrm{~A}$ regulation based merely on the coercion of the picketed business that may result from the uncoerced response of listeners to the picket's message is precisely the kind of content-based restriction that should receive exacting First Amendment scrutiny under current doctrine. On the other hand, regulation of aspects of labor picketing that coerce the listener and thereby induce a response irrespective of the picket's message should be subject only to the more permissive standards for incidental restrictions on expression.

Certainly consumer picketing can coerce the listener. Violence, serious physical threats, obstruction of entryways, and similar behavior that may sometimes be associated with picketing cannot claim First Amendment protection. ${ }^{76}$ But much consumer picketing, like that at issue in Safeco, is

sale restriction. See, c.g., Consolidated Edison Co. v. Public Serv. Comm'n, 447 U.S. 530 , 538 n.5 (1980); Gertz v. Robert Welch, Inc., 418 U.S. 323, 340 (1974) (libel); Miller v. California, 413 U.S. 15 (1973) (obscenity); Chaplinsky v. New Hampshire, 315 U.S. 568 (1942) (fighting words).

The Court's analysis has begun to break down at the margins, however. Thus, while conceding that "indecent speech" is within the scope of the First Amendment, a plurality of the Court led by Justice Stevens has accorded it a lower level of First Amendment protection from content-based restriction. See FCC v. Pacifica Found., 438 U.S. 726, 746-47 (1978) (opinion of Stevens, J.); see also infra p. 954. In addition, commercial speech, previously one of the categories of unprotected speech, has been brought within the scope of the First Amendment at an intermediate level of protection. See supra pp. 949-50. See generally A. CoX, supra note 42 (noting deterioration of two-tier First Amendment doctrine).

71. See Consolidated Edison Co. v. Public Serv. Comm'n, 447 U.S. 530, 540 (1980); infra note 111.

72. United States v. O'Brien, 391 U.S. 367, 377 (1969); see also Kovacs v. Cooper, 336 U.S. 77 (1949) (ordinance prohibiting sound amplifiers that emit "loud and raucous" noise upheld); supra note 49 (content-neutral regulations of picketing permissible). Ely has called the O'Brien standard "no gratuitous inhibition," and has pointed out that the standard is a weak one, offering little protection to expressive conduct. Ely, supra note 68, at 1488; cf. T. EMERSON, supra note 4, at 83-86 ("O'Brien is a serious setback for First Amendment theory.") Critics of the Court's two track analysis have focused on the weakness of the protections against content-neutral regulations of expressive activity. See Emerson, First Amendment Doctrine and the Burger Court, 68 CALIF. L. REV. 422, 473-74 (1980); Redish, The Content Distinction in First Amendment Analysis, 34 STAN. L. REV. 113 (1981).

73. See supra pp. $945-46$ (analyzing origin of illegal objective test).

74. See supra p. 941; supra note 31 (economic impact irrelevant to First Amendment status of picketing).

75. See supra note 41 (coercion of listeners as legitimate basis for regulation).

76. On the other hand, "the right to picket itself [cannot] be taken away merely because there may have been isolated incidents of abuse falling far short of violence occurring in the course of that picketing." Cafeteria Employees Local 302 v. Angelos, 320 U.S. 293, 296 (1943); see also Machesky 
wholly peaceful.

It might be argued that all picketing, no matter how peaceful, is inherently coercive of the listener and induces action irrespective of the content of its message. ${ }^{77}$ But Claiborne Hardware wholly undermines this argument: if the response to a peaceful picket were truly unrelated to the content of the picket's message, all picketing, or at least all picketing in front of a business establishment, should be subject to regulation on the same terms as labor picketing. Non-labor picketing, however, receives full First Amendment protection from content-based regulation. ${ }^{78}$ There is no reason why the standards developed in the non-labor context to identify and protect peaceful picketing ${ }^{79}$ would not be equally manageable in the context of consumer picketing by labor unions. Consumer picketing, like nonlabor picketing, should be subject only to reasonable content-neutral restrictions.

Justice Stevens, the author of the Court's opinion in Claiborne Hardware, suggested in his concurrence in Safeco, however, that in the labor context there is a more subtle mechanism of coercion by which even peaceful consumer picketing induces a response independent of the message conveyed. ${ }^{80}$ The characterization of labor picketing as a signal not entitled to First Amendment protection implies that the union message, perhaps because it triggers class loyalties, ${ }^{81}$ does not attain the level of rational discussion more deserving of First Amendment protection in the view of some theorists. ${ }^{82}$ Yet the logic of this suggestion, to the extent that it is any more than a bare expression of class bias, would require diminished First Amendment protection for appeals to deeply ingrained beliefs

v. Bizzell, 414 F.2d 283 (1969) (injunction that forbids peaceful picketing as well as abuses is overbroad and violates First Amendment). Similarly, in a civil action for damages, the recovery by the picketed business should be limited to the damages that it can demonstrate are the proximate result of specific incidents of coercive conduct, not of the peaceful inducement of listeners not to patronize the business. Cf. NAACP v. Claiborne Hardware Co., 102 S. Ct. 3409, 3437 (1982) (incidents of violence do not taint entire civil rights boycott; "A court must be wary of a claim that the true color of a forest is better revealed by reptiles hidden in the weeds than by the foliage of countless free-standing trees.")

77. See supra note 41 .

78. See supra pp. $947-49$.

79. See supra note 49 (content-neutral regulations of picketing permitted).

80. 447 U.S. 607,619 (1980).

81. Cr. Jaffe, supra note 19 , at $1037-44$ (picketing is expression that appeals to class solidarity and vaguer humanitarian impulses, and as such is communication).

82. Over forty years ago, the Court recognized that "[p]eaceful picketing is the workingman's means of communication." Milk Wagon Drivers Local 753 v. Meadowmoor Dairies, 312 U.S. 287, 293 (1941) (peaceful picketing in "context of violence" unprotected). But it simultancously expressed a preference for rational discussion as the paradigm of protected speech: "It must never be forgotten, however, that the Bill of Rights was the child of the Enlightenment. Back of the guarantee of free speech lay faith in the power of an appeal to reason by all the peaceful means for gaining access to the mind." Id. This emphasis on reasoned discussion, like Stevens' conception of a "signal," fails to recognize that "the nearer an idea is to acceptance, the less likely is abstract ratiocination to be the controlling factor." Jaffe, supra note 19, at 1038. 
of any kind. Most political speech, including the picketing in Claiborne Hardware, would be vulnerable to such an attack. ${ }^{83}$

The mere activity of picketing in front of a business establishment often communicates its own message: Support us by not supporting the business with which we have a dispute. But the meaning of the picketing activity is elaborated by the content of the picket signs and often by accompanying leaflets. Assuming that the message is not communicated by physical threats or other coercive conduct, the listener's response depends upon a free decision whether or not to support the objectives of the picketing group. ${ }^{84}$ If, as Justice Stevens appears to contend, the listeners' response to a picket is different when the subject is labor, that response is determined by the picket's expressive and informational content.

By prohibiting peaceful consumer picketing only when the subject is a labor dispute, the government has engaged in the regulation of expression based on its content. ${ }^{85}$ This Justice Stevens admits. ${ }^{86}$ For him, and for the minority of the Court that adheres to his novel view that regulation of content is often permitted under the First Amendment, ${ }^{87}$ this admission is not crucial. But according to the view of the First Amendment still held by the majority, content-based restrictions of expressive activity in a public forum should trigger the strictest First Amendment scrutiny. ${ }^{88}$

\section{B. Labor Picketing as Public Issue Picketing}

Perhaps recognizing that the extension of First Amendment protection to non-labor picketing undermines the existing rationale for permitting wholesale regulation of labor picketing, the Court appears to have adopted a new rationale founded on the openly content-based distinction between "public issue" picketing and labor picketing. ${ }^{89}$ According to this rationale,

83. See A. CoX, supra note 42 , at 47 (most political speech contains appeals to automatic responses).

84. A particular listener may be expected to respond differently to the messages of different pickets. For example, a moviegoer who would be indifferent or antagonistic to a union picket by striking employees of a movie theater may choose to honor a picket by a fundamentalist religious group of a movie depicting adultery in a positive light, or a picket by members of the John Birch Society of a movie starring an alleged Communist.

85. The distinction between labor and non-labor picketing is unquestionably based on content. See Carey v. Brown, 447 U.S. 455, 460 (1980).

86. NLRB v. Retail Store Employees Local 1001 (Safeco), 447 U.S. 607, 618 (1980) (Stevens, J., concurring).

87. See, e.g., FCC v. Pacifica Found., 438 U.S. 726, 746-47 (1978) (indecent speech subject to content regulation); Young v. American Mini Theatres, 427 U.S. 50, 70-71 (1976) (non-obscene "adult movies" subject to content regulation).

88. See supra pp. 951-52.

89. The suggestion that labor picketing does not concern a public issue and is therefore not entitled to First Amendment protection, see supra pp. 947-48, strikes at the heart of Thornhill, see supra p. 941. The Supreme Court recently applied this distinction in NAACP v. Claiborne Hardware Co., 102 S. Ct. $3409,3425-26$ (1982), to distinguish restrictions on labor picketing from restrictions on 
a union picket publicizing the anti-union practices of an employer does not concern a public issue, whereas a non-union picket publicizing the racially discriminatory practices of the same employer does. Only the nonlabor picket is entitled to First Amendment protection.

But a labor dispute, like a charge of race discrimination, is clearly of interest to members of the public not directly involved. ${ }^{90}$ Indeed, the success of the union's consumer picket depends upon public interest and support; absent the potential for such interest, there would be no need for restrictions. Just as the race discrimination of a single business reflects the broader phenomenon of racism and the problems of black citizens in a predominantly white society, a single labor dispute reflects the position of workers in an economic system based on private ownership and control of production. Each picket appeals to public solidarity with the picketing group in its particular dispute and in its larger struggle.91 Neither the labor dispute nor the discrimination charge is directly subject to electoral resolution, ${ }^{92}$ although each lies within the realm of governmental action. ${ }^{93}$

picketing in support of a civil rights boycott.

90. As one commentator has observed:

Decisions on what is to be produced in the system . . [,] on the allocation of resources to different lines of production, on the allocation of the labor force to different occupations and workplaces, on plant location, the technologies to be used in production, the quality of goods and services, innovation of new products ... are of momentous consequences for the welfare of any society. . . . The delegation of these decisions to the businessman does not diminish their importance or, considering their consequences, their public aspect.

C. LINDBLOM, POLITICS AND MARKETS 171 (1977).

Lindblom outlines some of the ways in which the business community removes from the political agenda the "grand issues of politico-economic organization: private enterprise, a high degree of corporate autonomy, protection of the status quo on distribution of income and wealth, close consultation between business and government, and restriction of union demands to those consistent with business profitability, among others." Id. at 205. The Supreme Court's exclusion of labor picketing from the scope of protection afforded "public issue" picketing serves these same ends.

91. Cf. Thornhill v. Alabama, 310 U.S. 88, 102-03 (1940) (each labor dispute is part of larger social movement). The Court relied on this aspect of the Thornhill decision in its extension of First Amendment protection to commercial advertising in Virginia State Bd. of Pharmacy v. Virginia Citizens Consumer Council:

We know of no requirement that, in order to avail themselves of First Amendment protection, the parties to a labor dispute need address themselves to the merits of unionism in general or to any subject beyond their immediate dispute. It was observed in Thornhill that "the practices in a single factory may have economic repercussions upon a whole region and affect widespread systems of marketing." Since the fate of such a "single factory" could as well turn on its ability to advertise its product as on the resolution of its labor difficulties, we see no satisfactory distinction between the two kinds of speech. 425 U.S. 748, 762-63 (1976) (citations omitted).

92. If the labor/public issue distinction rested on the relation of the subject matter to electoral politics, it might draw support from those scholars who would limit the scope of First Amendment protections to speech that directly concerns government policy. See Bork, Neutral Principles and Some First Amendment Problems, 47 IND. L.J. 1, 20 (1971). But this very narrow view of the First Amendment has never been endorsed by the Supreme Court. See Abood v. Detroit Bd. of Educ., 431 U.S. 209, 231-32 (1977). Other proponents of the theory that the First Amendment protects speech that contributes to democratic self-government define the scope of such speech much more broadly. See Meikeljohn, The First Amendment is an Absolute, 1961 SUP. CT. REV. 245, 255-57.

93. See Title VII of the Civil Rights Act of 1964,42 U.S.C. $\$ 2000$ e (1976) (equal employment 
The Court's conception of a public issue may be an historical one. The declaration in Thornhill that the facts of a labor dispute are of public concern occurred at a time of intense public discussion and corresponding legislative activity concerning the rights of employees and the role of unions. ${ }^{94}$ The intensity of this debate has subsided considerably, while the civil rights movement has generated a comparable level of public controversy and legislative activity in more recent times. But if it is this observation that lies behind the public issue/labor dispute distinction, the implications for political freedom are ominous. The decline of public controversy surrounding an issue should not be a rationale for denying to concerned groups First Amendment protection of the means of communication by which they might rekindle public controversy and stimulate a new period of reform.

It is perhaps not merely the decline of public controversy but the character of the resulting legislation that explains the transformation of the labor dispute from a public to a private issue in the eyes of the Court. In 1940, the Thornhill Court was forced to acknowledge that the employment relationship, previously regarded as a private contractual relationship between the individual worker and the employer, ${ }^{95}$ had long become not only a source of economic upheaval but also a matter of great public concern. Congress responded to that upheaval and public concern by attempting, through the NLRA, to contain and institutionalize labor-management disputes. ${ }^{96}$ The NLRA, as it has evolved over the years, attempts in many ways to reestablish in collective form the private nature of the employment relationship. The NLRA has been characterized as a quid pro quo: ${ }^{97}$ labor was granted the right to organize and to bargain collectively over a limited range of subjects governing the employer-employee relationship ${ }^{98}$ in turn, its ability to cause more widespread economic dis-

opportunity); NLRA, 29 U.S.C. $§ \S 151-169$ (1976) (regulation of labor-management relations).

94. See generally I. BERNSTEIN, TURBULENT YEARs 768-95 (1970) (summarizing turbulent history of labor movement from 1933-41).

95. See Sayre, Labor and the Courts, 39 YALE L.J. 682, 684-95 (1930) (collective activity by workers regarded initially as illegal conspiracy); see also E. FRANKFURTER \& N. GREENE, supra note 8 , at 4 (conspiracy and restraint of trade used as convenient grab bag terms to render group activity illegal).

96. See generally Stone, The Post-War Paradigm in American Labor Law, 90 YALE L.J. 1509 (1981) (labor law has removed labor disputes from public sphere to private dispute-resolution mechanisms).

97. This "quid pro quo" characterizes both the typical collective bargaining agreement, in which the union exchanges a no-strike promise for the employer's agreement to arbitrate grievances, $i d$. at 1528 , and the system of labor relations as a whole, which offers to unions certain legal protections in exchange for the surrender of many of their economic weapons, jd. at 1546. The "quid pro quo" is not an equal exchange. See Lynd, Investment Decisions and the Quid Pro Quo Myth, 29 CASE W. RES. L. REV. 396 (1979) (employer's duty to bargain narrower in scope than union's no-strike promise).

98. Only subjects not lying "at the core of entrepreneurial control" are subject to the duty to bargain. Fibreboard Paper Prods. Corp. v. NLRB, 379 U.S. 203, 223 (1964) (Stewart, J., concur- 
location was greatly circumscribed.99

Among the major limitations on labor is the prohibition of secondary pressures. Several provisions of the NLRA prohibit a union from broadening the impact of a labor dispute by urging the involvement of the employees or customers of an employer not directly involved in the dispute. ${ }^{100}$ These prohibitions encompass, as this Note has demonstrated, various forms of non-coercive communication to consumers.

The Court's distinction between labor and public issue picketing accommodates the congressional labor policy of confining labor disputes to the parties themselves, without abrogating First Amendment protection of non-labor picketing. At the same time, however, it introduces a dangerous innovation into First Amendment doctrine. By establishing a principle of constitutional adjudication that allows Congress to remove controversial matters from public discussion without encountering the strictest judicial scrutiny of the motivating state interest and the means of promoting that interest, the Court's distinction seriously undermines the First Amendment. ${ }^{101}$

\section{Commercial Advertising: An Incident of the Commercial Transaction}

It has been suggested by one commentator that consumer picketing, like advertising, is "economic speech" and should therefore also receive the intermediate level of protection afforded by the Central Hudson test. ${ }^{102}$ There is, however, a fundamental difference between the messages involved. Speech that does no more than propose a commercial transaction is a mere incident of that transaction and should arguably not be protected by the First Amendment at all. ${ }^{103}$ The interest of the public and the ad-

ring). See also First Nat'l Maintenance Corp. v. NLRB, 452 U.S. 666 (1981) (decision to close part of business not mandatory subject of bargaining). See generally Lynd, supra note 97 (employer's duty to bargain narrow in scope).

99. See Lynd, The Right to Engage in Concerted Activity After Union Recognition: A Study of Legislative History, 50 IND. L.J. 720, 720-30 (1975) (union recognition limits workers' right to use economic pressures).

100. See 29 U.S.C. $§ 158(b)(4)$ (1976) (secondary boycotts and sympathy strikes prohibited); id. $\S$

158(e) ("hot cargo clause," under which employer agrees not to handle non-union goods, prohibited).

101. There is, for example, no apparent reason why the Court could not, by the same principle, defer to a congressional decision that employment discrimination is also a private matter between employers and minority employees, under the supervision of the Equal Employment Opportunity Commission.

102. See A. CoX, supra note 42 , at $47-48$.

103. This argument has been developed fully in Jackson \& Jeffries, supra note 59. Justice Rehnquist, the sole dissenter from the decisions protecting commercial speech, has taken a similar position. See, e.g., Central Hudson Gas \& Elec. Co. v. Public Serv. Comm'n, 447 U.S. 557, 588-99 (1980); Virginia State Bd. of Pharmacy v. Virginia Citizens Consumer Council, 425 U.S. 748, 781-90 (1980). Justice Rehnquist, however, is not very solicitous of freedom of expression in general, and particularly not in the labor context. See Lind, Justice Rehnquist: First Amendment Speech in the Labor Context, 8 Hastings CONST. L.Q. 93 (1980). 
vertiser in "the free flow of commercial information"104 through promotional advertising is no different from their interest in the free flow of goods and services, which has, since the decline of the Lochner era, been deemed an appropriate object of regulation. Indeed, the Court's articulated rationale for protecting commercial speech rests in large part on the important function of advertising in the free enterprise system ${ }^{105}$ and not on its relation, dubious at best, to the philosophical foundations of the First Amendment. ${ }^{106}$

Unlike other categories of speech seemingly unrelated to the philosophical values underlying the First Amendment, commercial advertising is readily identifiable; its definition has never involved the intractable problems the Court has encountered, for instance, in its obscenity doctrine. ${ }^{107}$ Although line drawing is never an easy task, the line between commercial advertising and protected speech would seem to pose no significant threat to First Amendment freedoms. ${ }^{108}$ Indeed, the Court itself has conceded that the extension of full First Amendment protection to advertising could weaken protection for other forms of speech. ${ }^{109}$ In spite of these considerations, however, the First Amendment has been invoked to protect an incident of economic liberty. ${ }^{10}$ By contrast, consumer picketing appeals inherently to policical, ideological, or class sympathies. The union picket aims to persuade the consumer to forego, in the interest of solidarity with the union's admittedly economic aims, whatever economic benefit drew her to the business or product. Therefore, unlike mere commercial advertising, consumer picketing is an exercise of political freedom that implicates the very core of First Amendment protection. This difference calls

104. Virginia State Bd. of Pharmacy v. Virginia Gitizens Consumer Council, 425 U.S. 748, 765 (1976).

105.

So long as we preserve a predominantly free enterprise economy, the allocation of our resources in large measure will be made through numerous private economic decisions. It is a matter of public interest that those decisions, in the aggregate, be intelligent and well-informed. To this end, the free flow of commercial information is indispensable.

Id. at 765. See generally Jackson \& Jeffries, supra note 59, at 25-40 (commercial speech doctrine protects economic liberty).

106. See Jackson \& Jeffries, supra note 59, at 14-25; see also Baker, supra note 59.

107. See Paris Adult Theatre I v. Slaton, 413 U.S. 49, $79-80$ (1973) (Brennan, J., dissenting) ('IW]e have been unable to provide 'sensitive tools' to separate obscenity from other sexually oriented but constitutionally protected speech, so that efforts to suppress the former do not spill over into the suppression of the latter.")

108. See Jackson \& Jeffries, supra note 59, at 25 ("Both reason and experience suggest that the distinction between commercial speech and protected speech is relatively casy to maintain.")

109. See Ohralik v. Ohio State Bar Ass'n, 436 U.S. 447, 456 (1978) ("To require a parity of constitutional protection for commercial and non-commercial speech alike could invite dilution, simply by a leveling process, of the force of the Amendment's guarantee with respect to the latter kind of speech.")

110. See Central Hudson Gas \& Elec. Co. v. Public Serv. Comm'n, 447 U.S. 557, 588-99 (Rehnquist, J., dissenting); see also Jackson \& Jeffries, supra note 59, at 25-40. 
for a return to the priorities established in Thornhill and Valentine.

\section{The Incorporation of Substantive Economic Values into First Amendment Doctrine}

When reviewing a restriction on peaceful communication concerning matters of public interest in a public forum, the Court's strong reluctance to approve content-based restrictions on speech becomes a virtually insurmountable barrier. ${ }^{111}$ It is this barrier that the Court circumvents by treating all labor picketing directed at consumers only as economic activity not entitled to First Amendment protection. The Court's cursory approval of the NLRA prohibition of secondary consumer picketing in Safeco implicitly held that the state interest in preventing the economic coercion of neutral employers justifies any resulting restriction of expressive activity. ${ }^{112}$

111.

Once a forum is opened up to assembly or speaking by some groups, government may not prohibit others from assembling or speaking on the basis of what they intend to say. Selective exclusions from a public forum may not be based on content alone, and may not be justified by reference to content alone.

Police Dept. v. Mosley, 408 U.S. 92, 96 (1972). See also Carey v. Brown, 447 U.S. 455, 462-63 (1980); Hudgens v. NLRB, 424 U.S. 507, 520 (1976).

As the uncompromising language in Mosley suggests, the exceptions to the prohibition of contentbased restrictions are exceedingly rare. The Court's special solicitude for the integrity of the judicial process led it to uphold a prohibition on picketing in front of a courthouse where the picketing was related to a matter being considered by the court. See Cox v. Louisiana, 379 U.S. 559 (1965). In addition, subject matter restrictions, which arc, of course, based on content, have survived on rare occasions. See, e.g., Greer v. Spock, 424 U.S. 828 (1976) (government may prohibit partisan political speech on military base); Lehman v. City of Shaker Heights, 418 U.S. 298 (1974) (opinion of Blackmun, J.) (plurality allowed city transit system to refuse to accept partisan political advertising although it accepted commercial advertising). The Court, however, has recently placed these cases in perspective: "Greer and Lehman properly are viewed as narrow exceptions to the general prohibition against subject matter distinctions." Consolidated Edison Co. v. Public Serv. Comm'n, 447 U.S. 530, 539 (1980). In both cases the public facility to which access was sought was not an open forum such as the streets and sidewalks on which picketing takes place.

112. See supra pp. 944-46. The policy behind the NLRA prohibition of secondary consumer picketing, NLRA $\S 8(\mathrm{~b})(4)(\mathrm{ii})(\mathrm{B})$, has two facets: the state interest in regulating commerce and the state interest in protecting individual private businesses from this kind of economic harm. These two facets are expressed in a single sentence in NLRB v. Retail Store Employees Local 1001: "ISecondary] picketing spreads labor discord by coercing a neutral party to join the fray." 447 U.S. 607,616 (1980). Indeed, these two facets are only two ways of viewing the same state interest. Congress' exercise of its commerce power in this provision reflects the policy judgment that the protection of individual businesses from the economic harm that may result from the peaceful publicizing of a labor dispute is in the best interest of the economy. It is not surprising that the health of the whole economy is identified with the health of the business community rather than that of the labor community. See generally C. LINDBLOM, supra note 90, at 170-213 (public policy substantially shaped by need to create favorable business climate).

That the predominant concern of Congress was to protect private business interests from economic harm is evident in the language of $\S 8(\mathrm{~b})(4)(\mathrm{ii})(\mathrm{b})$, in its legislative history, see NLRB v. Fruit \& Vegetable Packers Local 760, 377 U.S. 58, 63-71, 82-92 (1964) (summarizing legislative history: statements by those who favored restriction reflect overriding concern with "fairness" to "neutral" employers; no mention is made of aggregate effects of such picketing on national commerce), and in Congress' reliance on private enforcement, see 29 U.S.C. \$ 160(1) (1976) (upon application to NLRB, employer may obtain injunction against secondary pressures, including picketing); LaborManagement Relations Act $\S 303,29$ U.S.C. $§ 187$ (1976) (employer who incurs loss as result of 
That holding effectively raised to preeminent constitutional status the right of a business to carry on its affairs without interference from appeals for public support in labor disputes.

The Court's unwarranted deference to restrictions on labor picketing stands in stark contrast to its exacting First Amendment scrutiny of restrictions on commercial advertising. These commercial speech decisions, like the substantive due process decisions of the Lochner era, elevate private economic interests to the status of constitutional rights. ${ }^{113}$ This juxtaposition of First Amendment judicial restraint and activism ${ }^{144}$ appears contradictory, however, only if legal form is allowed to obscure political substance. Deference to restrictions on labor picketing and activist protection of commercial advertising are both consistent with a substantive economic ideology of free enterprise similar to that which animated the Court in the Lochner era.

Both a union picket and a commercial advertisement are intended to influence consumers' choices among goods and services. To the extent that each is successful, some business, either the business picketed by the union or the advertiser's competitor, will suffer a corresponding economic loss. But advertising influences these consumer choices and inflicts economic loss in a manner that promotes the system of economic competition, whereas the union picket influences consumer choices through appeals to class loyalty and political sympathy that are inconsistent with economic competition.

These same distinctions were drawn under the common-law doctrine of interference with business relations. Under this doctrine, elevated to constitutional status by the Supreme Court in the Lochner era, union activity that harmed a business was tortious and enjoinable, while "reasonable competition," however harmful, was not. ${ }^{115}$ The labor picketing doctrine represented by $S a f e c o$, together with the commercial speech doctrine represented by Central Hudson, reintroduces these economic values into the Constitution."16 The Supreme Court has thus incorporated into First Amendment doctrine a hierarchy of values that is more consistent with the free enterprise system than with the system of freedom of expression.

secondary picketing may sue for damages in federal district court).

113. See supra pp. 957-58 (analogy between substantive due process and commercial speech cases).

114. Cr. A. Cox, supra note 42 , at $32-38$ (noting doctrinal inconsistency between exacting scrutiny in commercial speech cases and deferential stance toward "indecent speech").

115. See supra p. 939.

116. Similarly, the consumer has a constitutionally cognizable right to the information conveyed by an advertiser, see Virginia State Bd. of Pharmacy v. Virginia Citizens Consumer Council, 425 U.S. 748, 756-57, 763-64 (1976), but no acknowledged right or even interest in receiving the information conveyed by a union picket, see supra pp. 943-44. 


\section{The Speech or Debate Clause Protection of Congressional Aides}

The speech or debate clause of the Constitution provides that "for any Speech or Debate in either House, they [Senators and Representatives] shall not be questioned in any other Place." The Supreme Court did not have occasion to construe the clause until 1881. Then, in Kilbourn v. Thompson, ${ }^{2}$ the Court held that the purpose of the clause, to protect the independence of Members of Congress in the performance of their legislative responsibilities, ${ }^{3}$ would be ill-served by a literal reading of the phrase "Speech or Debate":

It would be a narrow view of the constitutional provision to limit it to words spoken in debate. The reason of the rule is as forcible in its application to written reports presented in that body by its committees, to resolutions offered, ... . and to the act of voting . . . . In short, to things generally done in a session of the House by one of its members in relation to the business before it. ${ }^{4}$

The small body of speech or debate case law built up after Kilbourn ${ }^{5}$ deals principally with whether particular activities not adverted to in Kilbourn fall within the set of legislative functions for which immunity is to be conferred. ${ }^{\circ}$

I. U.S. Const. art. I, § 6, cl. 1.

2. 103 U.S. 168 (1881).

3. Id. at 203. In support of its broad view of the purpose of the clause, the Court cited an opinion by Chief Justice Parsons of the Massachusetts Supreme Court, interpreting a similar provision in that state's constitution. Parsons wrote:

These privileges are thus secured, not with the intention of protecting the members against prosecutions for their own benefit, but to support the rights of the people, by enabling their representatives to execute the functions of their office without fear of prosecutions, civil or criminal. I therefore think that the article ought not to be construed strictly, but liberally, that the full design of it may be answered. I will not confine it to delivering an opinion, uttering a speech, or haranguing in debate; but will extend it to the giving of a vote, to the making of a written report, and to every other act resulting from the nature, and the execution, of the office.

Coffin v. Coffin, 4 Mass. 1, 27 (1808).

4. 103 U.S. 168, 203 (1881) (emphasis added).

5. The clause has been addressed by the Supreme Court in only ten cases other than Kilbourn, all but one of which were decided in the last fifteen years: Hutchinson v. Proxmire, 443 U.S. 111 (1979); United States v. Helstoski, 442 U.S. 477 (1979); Eastland v. United States Servicemen's Fund, 421 U.S. 491 (1975); Doe v. McMillan, 412 U.S. 306 (1973); Gravel v. United States, 408 U.S. 606 (1972); United States v. Brewster, 408 U.S. 501 (1972); Powell v. McCormack, 395 U.S. 486 (1969); Dombrowski v. Eastland, 387 U.S. 82 (1967); United States v. Johnson, 383 U.S. 169 (1966); Tenney v. Brandhove, 341 U.S. 367 (1951).

6. Sec, e.g., Dombrowski v. Eastland, 387 U.S. 82 (1967) (conduct of committee investigation); Tenney v. Brandhove, 341 U.S. 367 (1951). 
In 1972, the Court further extended the reach of the clause by holding, in Gravel v. United States,' that not only Senators and Representatives, but also their aides, are entitled to invoke the protection of the clause "insofar as the conduct of the latter would be a protected legislative act if performed by the Member himself." While the Court's extension of immunity to legislative aides seemed clear enough as applied to the facts in Gravel, in other contexts it has raised two concerns.

The first is that the Court's opinion did not define who qualifies as an aide for purposes of speech or debate clause protection. The Gravel case involved a member of Senator Gravel's personal staff who, it is clear from the record, worked closely with the Senator in preparation for the subcommittee hearing that gave rise to the case. ${ }^{9}$ There are, however, other varieties of legislative branch employees who are not so closely bound to individual Members of Congress; these include committee staff members, employees of either House as a whole, and staff members of auxiliary legislative entities, such as the General Accounting Office. The Gravel decision left open the question of whether congressional employees who are not closely bound to individual Members of Congress should be entitled to share in the immunity established by the speech or debate clause.

The second concern generated by the Gravel holding is that it too indiscriminately extends speech or debate protection to those aides who fall within the class of persons eligible to invoke the privilege, however that class may be defined. The Gravel decision permits aides to assert speech or debate clause protection directly, subject only to a Member's veto, and fails to require a nexus between a Member of Congress and the act for which an aide seeks immunity. Thus, the extension of immunity effected in Gravel is broader than it need be to safeguard the legislative independence of Senators and Representatives themselves. Moreover, by affording aides the opportunity to invoke immunity for acts they undertake on their own accord, the Gravel holding invites abuse.

After analyzing the two concerns raised by Gravel, this Note proposes a new standard for speech or debate protection, one that would incorporate a functional definition of the term "aide." Under the proposed standard, immunity would be available to aides only in circumstances in which the independence of Members of Congress, as distinguished from the independence of their aides, may be presumed to be implicated.

7. 408 U.S. 606 (1972).

8. Id. at 618 .

9. United States v. Doe, 332 F. Supp. 930,937 (D. Mass. 1971). 
I. Speech or Debate Glause Interpretations Prior to Gravel: Intimations of Limited Congressional Staff Immunity

In Kilbourn v. Thompson, ${ }^{10}$ the Supreme Court ruled that the speech or debate clause protected Members of the House of Representatives from liability for a resolution ordering the illegal arrest of the plaintiff," but that damages could be assessed against the Sargeant-at-Arms of the House, who had carried out the arrest. ${ }^{12}$ In reaching this conclusion, the Court did not raise the possibility that a congressional staff member, such as the Sargeant-at-Arms, might be eligible for some measure of speech or debate immunity.

That possibility surfaced in the Court's next speech or debate clause decision, some seventy years later in Tenney v. Brandhove. ${ }^{13}$ After noting that the defendants in Tenney were Members of Congress, the Court observed: "Legislative privilege in such a case deserves greater respect than where an official acting on behalf of a legislature is sued [as in Kilbourn] or the legislature seeks the affirmative aid of the courts to assert a privilege."14 Thus, the Court implied that it would accord some respect to the assertion of speech or debate clause immunity by an official acting on behalf of Congress.

The Court was more explicit about that prospect in Dombrowski v. Eastland,$^{15}$ although it again declined to extend immunity to a congressional aide. Giting its dictum in Tenney, the Court declared that it had "held . . . that this doctrine [of speech or debate immunity] is less absolute, although applicable, when applied to officers or employees of a legislative body, rather than to legislators themselves." ${ }^{16}$ For the first time, then, the Court explicitly took the position that congressional staff members enjoyed some degree of speech or debate protection. The Court did not explain, however, what a less-than-absolute immunity might amount to or how its impact should be assessed in particular cases. Nor did the Court set forth a rationale for the extension of immunity to aides.

Powell v. McCormack, ${ }^{17}$ the last of the Court's decisions prior to Gravel to bear upon the issue of staff immunity, did little to clarify the Court's position. Powell involved a challenge by Representative Powell

10. 103 U.S. 168 (1881).

11. Id. at 205 .

12. Id. Kilbourn was eventually awarded a $\$ 20,000$ judgment against Thompson, the Sargeant-atArms. See Kilbourn v. Thompson, 11 D.C. (MacArth. \& M.) 401, 432 (1883). Fortunately for Thompson, Congress passed a special appropriation to pay the judgment. J. HAMILTON, THE POWER TO PROBE: A STUDY OF CONGRESSIONAL INVESTIGATIONS $88 \mathrm{n} .^{*}$ (1977).

13. 341 U.S. 367 (1951).

14. Id. at 378 (emphasis added).

15. 387 U.S. 82 (1967).

16. Id, at 85.

17. 395 U.S. 486 (1969). 
and some of his constituents to his exclusion by and from the House of Representatives. The Court dismissed Powell's suit against Members of the House, but ruled that his action could be maintained against the House employees who implemented the resolution excluding Powell. ${ }^{18}$ What was remarkable about the Court's discussion of the speech or debate question in Powell was not what it concluded, but what it excluded: any reference to the potential applicability of speech or debate clause immunity to congressional aides. Indeed, despite its declaration to the contrary in Dombrowski, the Court asserted categorically in Powell that "[f]reedom of legislative activity and the purposes of the Speech or Debate Glause are fully protected if legislators are relieved of the burden of defending themselves." 19 The confusion was not resolved until the Court's decision in Gravel.

\section{An Assessment of the Gravel Standard}

On the evening of June 29, 1971, Senator Mike Gravel convened a meeting of the Senate Subcommittee on Public Buildings and Grounds, a subcommittee he chaired. Gravel proceeded to read excerpts from a history of the Vietnam War that had been prepared by the Department of Defense and classified as Top Secret-Sensitive. The Senator then placed the entire forty-seven volume study, popularly referred to as the Pentagon Papers, into the subcommittee record, making it accessible to the press and, through the press, to the public.

Leonard Rodberg, who had been added to Gravel's personal staff on the morning of June 29, had assisted the Senator in preparation for the subcommittee meeting. Shortly thereafter, Rodberg was subpoenaed to testify before a federal grand jury that was investigating possible violations of law in connection with the public release of the Pentagon Papers. Rodberg moved to quash the subpoena, and Senator Gravel was permitted to intervene on Rodberg's behalf in the district court proceeding. The Senator argued that requiring Rodberg to appear and testify before the grand jury would trench on the legislative independence reserved to Gravel as a Member of Congress by the speech or debate clause. ${ }^{20}$

Both the district court ${ }^{21}$ and the court of appeals ${ }^{22}$ in the case held that

18. Id. at 506 .

19. Id. at $\mathbf{5 0 5}$ (footnote omitted).

20. Gravel v. United States, 408 U.S. 606, 608-10 (1972).

21. United States v. Doe, 332 F. Supp. 930 (D. Mass. 1971). The district court held that neither Rodberg nor other persons could be questioned by the grand jury regarding Gravel's conduct at, or in preparation for, the subcommittee hearing. Id. at 938. They could, however, be questioned about Gravel's endeavor to arrange for private publication of the Pentagon Papers, since that undertaking, in the court's view, was not within the range of legislative activity protected by the clause. Id. at 936 . As to Rodberg's own actions, the court held that speech or debate clause immunity would be available 
Rodberg's activities at, and in preparation for, the subcommittee hearing were protected by the speech or debate clause. The Supreme Court agreed and, in so doing, broke in two respects from the pattern that had emerged in its earlier decisions-first, by actually extending speech or debate immunity to a congressional aide, ${ }^{23}$ and, second, by announcing a standard for such extensions that, as the Court noted, involved a "refusal to distinguish between Senator and aide in applying the Speech or Debate Clause." 24

On the second point, if not the first, the Court also departed sharply from the holdings by the district court and the court of appeals. Both of these courts had required, as a prerequisite to the extension of immunity, that a connection be demonstrated between Member and aide with respect to the particular one of the aide's actions for which immunity was sought. Under the standard set forth by the Supreme Court, no such linkage need be established; any act that would be protected under the speech or debate clause when performed by a Member of Congress is also to be protected when performed by an aide. ${ }^{25}$ The Court made no mention of this essential difference between its holding and the holdings of the district court and the court of appeals. ${ }^{26}$

\footnotetext{
"to the extent that they were undertaken at the Senator's direction either at a meeting of the Subcommittee on Public Buildings and Grounds or in preparation for and intimately related to said meeting." Id. at 938. Rodberg's activities in connection with the subcommittee meeting were afforded protection because they "would have been legislative acts, and therefore privileged, if performed by the Senator personally." Id. at 937-38. As already indicated, the court did not consider efforts to secure broader public dissemination of the Pentagon Papers as meeting this standard.

The court grounded its extension of immunity to Rodberg on its observation that Members of Congress depend considerably for their effectiveness upon the services of confidential assistants. Id. at 937. It cited Dombrowski v. Eastland for the proposition that "employees have rights flowing from the Speech or Debate Clause," id. at 937 n.7, but it emphasized that the privilege established by the clause "belongs to Congressmen only and not to their assistants and aides," id. at 934.

22. United States v. Doe, 455 F.2d 753 (1st Cir. 1972). The court of appeals declared that the need for legislators to be able to repose complete confidence in their personal aides required that a Member and the Member's aide be "treated as one." Id. at 761. But this bold expression of equivalency, which the Supreme Court was to adduce in its own opinion, Gravel v. United States, 408 U.S. 606, 616 (1972), overstated the lengths to which the court went in extending immunity to congressional aides. In its next sentence, the court of appeals conceded that there might properly be some exceptions to the suggested congruence. 455 F.2d at 761. The court then observed that the posited "synonymity is founded upon the relationship, not on the fact of employment. Rodberg, for example, is not protected from inquiry as to events unconnected with the intervenor at the time of occurrence." Id. Thus, had Rodberg undertaken legislative acts on his own accord while in the employ of Gravel, he would have been without the protection of the speech or debate clause for those acts. It seems evident that the court intended that a Member and his aide be treated as a unit under the clause only when they are actually functioning as a unit in carrying out particular legislative activities-as, for instance, Gravel and Rodberg had functioned in preparing for the subcommittee meeting.

23. Gravel v. United States, 408 U.S. 606, 628-29 (1972).

24. Id. at 622 .

25. Id. at 618 .

26. Instead, the Court quoted selectively from the opinions below, professing, for example, to agree with the First Circuit that Member and aide should be "treated as one." Id. at 616. The Court also quoted the district court to the effect that the speech or debate clause barred inquiry into "things done by Dr. Rodberg as the Senator's agent or assistant" that would have been privileged acts if
} 
The Court indicated that its holding was based on

what the Senate of the United States urgently presses here: that it is literally impossible, in view of the complexities of the modern legislative process . . . for Members of Congress to perform their legislative tasks without the help of aides and assistants; [and] that the dayto-day work of such aides is so critical to the Members' performance that they must be treated as the latter's alter ego . . . . ${ }^{27}$

In fact, the Senate, in its brief to the Court, had proposed only that aides be protected when "acting for their employer-Member."28 While the Court did not explain its reasons for eliding from the importance of aides to the necessity of automatically treating them as alter egos of Members, it did assert in a general way that its holding furthered the "fundamental purpose" of the speech or debate clause, that of "freeing the legislator from executive and judicial oversight that realistically threatens to control his conduct as a legislator." 29 The Court added in a footnote that since an aide's protection under the speech or debate clause is derivative of a Member's privilege, the Member can override an aide's assertion of immunity. ${ }^{30}$

\section{A. The Universe of Persons Eligible for Speech or Debate Clause Protection}

The Court in Gravel did not demarcate the class of persons-_aides"-to which it had afforded speech or debate immunity. The aide to whom protection was granted in Gravel was on the personal staff of a Senator; ${ }^{31}$ he worked for that Senator only, and he was paid for his work out of that Senator's allotment of salary money. There are other aides who assist Members of Congress but who are not closely identified

carried out by the Senator, id. (quoting Doe, 332 F. Supp. at 937-38); the Court did not, however, indicate that the district court had been referring, with the phrase "things done . . . as the Senator's agent or assistant," to those activities that Rodberg had undertaken "at the Senator's direction," Doe, 332 F. Supp. at 938.

27. Gravel, 408 U.S. at 616-17.

28. Brief for the Senate of United States at Il, United States v. Gravel, 408 U.S. 606 (1972). The Court seems to have lifted from the Senate brief the idea that aides should be viewed as the alter egos of Members; but while the Court assumes in its rhetoric and its holding that aides invariably act as the alter egos of their legislator-superiors, the Senate was more circumspect: "A Representative or Senator simply cannot function in the Congress without aides who are so intimately involved and identified with him as to be in many instances his alter ego." Id. (emphasis added). What the Senate had argued to the Court, then, was that aides should be eligible for speech or debate immunity only in those instances in which the aides actually function, in the performance of legislative tasks, as the alter egos of Members-that is, when the aides are "acting for their employer-Member." Id.

29. 408 U.S. at 618 .

30. Id. at 622 n.13.

31. Affidavit of Mike Gravel, Joint Appendix at ll, Gravel v. United States, 408 U.S. 606 (1972). 
with any particular Member. To cope with its ever-expanding workload, ${ }^{32}$ Congress has created what some have termed a legislative bureaucracy $^{33}$ - made up not only of personal aides, but also of committee and subcommittee staffs, staff members of either House as a whole, and the staff of auxiliary legislative agencies, such as the General Accounting Office and the Congressional Budget Office. ${ }^{34}$ Nearly 40,000 people are now on the legislative branch payroll; $;^{35}$ of these, only one quarter are personal staff employees. ${ }^{36}$ In addition to paid staff, Members are often aided in their legislative tasks by others who are not on the payroll, including interns, fellows nominated and subsidized by outside organizations, members of the academic community, and personal friends and associates of Members. ${ }^{37}$

In the absence of a definition of the term "aide," the Court's holding in Gravel is susceptible to what might be called an underinclusive interpretation. Since the aide involved in the Gravel case was on the personal staff of a Senator, and since the Court used a possessive pronoun ("his") to indicate the postulated relationship between an aide and a Member, it might be supposed that the Court intended to extend the protection of the speech or debate clause principally to those who work on the personal staffs of Members of Congress. ${ }^{38}$ The Court's use of the term "alter ego" would lend support to this thesis; a staff member of the General Accounting Office, for example, is not likely to function as the "alter ego" of an

32. See infra note 47.

33. See, e.g., M. Malbin, Unelected Representutives 4 (1980); Cameron, The Shadow Congress the Public Doesn't Know, ForTUNE, Jan. 15, 1979, at 39.

34. See H. FoX, JR. \& S. HAMMIONd, CongresSional STAFFs: The InVisible Forge IN AMERICAN LAWMIAKING; 130-42 (1977).

35. Id. at 3.

36. M. MALBIN, supra note 33 , at 256 .

37. H. FOX, JR. \& S. HAMMOND, supra note 34, at 137-39.

38. The Supreme Court has extended immunity in two cases since Gravel to congressional employees not on the personal staffs of Members. In Doe v. McMillan, 412 U.S. 306 (1973), the Court held that the staff members of a House committec, including a consultant and a temporary investigator, were entitled to speech or debate clause protection for their work on hearings and a committee report that described the disciplinary problems of specifically identified students in the District of Columbia school system. Id. at 312. While the Court did not accord protection to the Superintendent of Documents and the Public Printer, also named as defendants in the case for having distributed the committee report both within and beyond Congress, the Court's decision in this regard rested on its finding that public distribution of such a report fell outside the sphere of legislative activity comprehended by the speech or debate clause. Id. at 315-16. In Eastland v. United States Servicemen's Fund, 421 U.S. 491 (1975), the Court granted speech or debate immunity to the counsel of a Senate subcommittee, observing that "[w]e draw no distinction between the Members and the Chief Counsel." Id. at 507. Since committee staff members are typically hired by the chair or ranking minority member of the committee on whose payroll they appear, R. RIPLEY, POWER IN THE SENATE 201-02 (1969), these aides may be viewed as de facto personal staff assistants to the chair or ranking minority member. The Court has yet to extend immunity to an aide to either House as a whole, or to a staff member of an auxiliary legislative entity; these categories of legislative employees do not so readily fit, in their "day-to-day work," Gravel, 408 U.S. at 616, the "alter ego" model set out in Gravel. 


\section{individual Member of Congress. ${ }^{39}$}

This reading of the Gravel holding would have courts draw generalized conclusions about the eligibility of congressional staff members for speech or debate protection on the basis of organizational placement and typical reporting relationships. Claims of staff immunity, however, arise in connection with specific acts. In order to determine whether a Member's legislative independence would be compromised by the questioning of a congressional aide, it is necessary to focus analysis on the particular act at issue, and to determine whether the linkage between the Member and the aide was such with respect to that act that the independence of the legislator would be impinged upon by the proposed questioning.

Organization charts are inadequate guides for this sort of analysis. For example, while an institutional legislative staff member-such as the Clerk of the House or an analyst at the General Accounting Office-may not have so comprehensive an identification with any particular Member of Congress as to function as the Member's alter ego, he or she may on occasion work with or for a Member on a particular legislative task. ${ }^{40}$ Questioning an institutional aide about such a task could encroach upon a legislator's independence just as much as questioning a member of the legislator's personal staff about that task. ${ }^{41}$

\section{B. Staff Autonomy}

The standard set forth in Gravel permits congressional aides to assert speech or debate protection for facially legislative acts that they undertake of their own accord. This creates a serious potential for abuse; for example, the clause may be used by aides to shield themselves from liability for what would otherwise be treated as libels or tortious invasions of privacy. As the Court has itself observed: "In its narrowest scope, the Clause is a very large, albeit essential, grant of privilege. It has enabled reckless men to slander and even destroy others with impunity, but that was the conscious choice of the Framers." ${ }^{32}$ The Framers surely did not anticipate,

39. For an instance of the underinclusiveness of Gravel, see In re Grand Jury Investigation, 587 F.2d 589, 597 (3rd Cir. 1978) ("Of course, in a very broad sense the Clerk (of the House) is an aide to every member of the House; but his relationship with any particular member is not such that there is a realistic possibility that questioning of him, hostile or friendly, will have an inhibiting effect upon that member's performance.")

40. See H. FoX, JR. \& S. HAMMOND, supra note 34 , at 130-35.

41. Moreover, an institutional aide who works on a legislative project for multiple Members of Congress-for example, a congressional committee or subcommittee, or a regional caucus-should not be barred from speech or debate protection because he or she is serving more than one Member. If an aide is eligible for speech or debate immunity where the legislative independence of one Member is at stake, then a fortiori the aide should be eligible when the independence of more than one Member is in danger.

42. United States v. Brewster, 408 U.S. 501, 516 (1972) (footnote omitted). 
however, that the authority to invoke this privilege, and to avoid legal accountability for misconduct, would be extended to many thousands of unelected legislative employees.

The purposes of the speech or debate clause are served if a Member of Congress asserts immunity in order to protect an aide from questioning that could infringe upon the Member's legislative independence. But the Court has offered no explanation of why, in order "to protect the integrity of the legislative process," $" 43$ it is necessary to extend to aides the authority to invoke immunity under the clause for their own self-initiated activities. Questioning of an aide in such circumstances does not "realistically threaten to control [a Member's] conduct as a legislator." ${ }^{\text {44 }}$

The Supreme Gourt seems to have assumed in framing the Gravel rule that aides invariably work side-by-side with, and under the close supervision of, Members of Congress. That was apparently an accurate understanding of the working relationship between Gravel and Rodberg in connection with the specific subcommittee meeting involved in the case. That model of Member-staff interaction, however, does not square with everyday experience in the reticular modern Congress. By any measure, the workload of Congress has expanded enormously in the last several decades. ${ }^{45}$ Staff sizes have been enlarged dramatically to keep pace. ${ }^{46}$ Congressional aides now play vital roles in almost every aspect of the legislative process, from drafting bills and speeches to conducting investigations. ${ }^{47}$

43. Id. at 507 .

44. Gravel v. United States, 408 U.S. 606, 618 (1972).

45. See H. FOX, JR. \& S. HAMMOND, supra note 34, at 27; see also Huitt, The Internal Distribution of Influence: The Senate, in THE CONGRESS AND AMERICA's FUTURE 91, 112 (D. Truman ed., $2 d$ ed. 1973) (current workload would be "unthinkable" without expanded staff). Between the 85th Congress (1957-58) and the 95th Congress (1977-78), the number of committee and subcommittee meetings in the House of Representatives increased from 3,750 to 6,771; in the Senate, the number of such meetings rose from 2,748 to 6,656 . M. MALBIN, supra note 33 , at 258 . The number of recorded votes increased during this period from 193 to 1540 in the House and from 313 to 1156 in the Senate. Id.

Similarly, between the 80th Congress (1947-48) and the 94th Congress (1975-76), the number of bills introduced in the House of Representatives rose from 7,611 to 16,982. COMMIISSION ON ADMINISTRATIVE REVIEW, ADMINISTRATIVE REORGANIZATION AND LEGISLATIVE MANAGEMENT, H.R. DOC. No. 232, 95th Cong., 1st Sess. 39 (1977) [hereinafter cited as OBEY COMMISSION REPORT]. The caseload level in the typical Representative's office-that is, the number of constituent problems investigated or mediated-doubled in the ten years between 1965 and 1975. Id. at 41. The volume of mail Congressmen received tripled between 1969 and 1975. Id.

46. Between 1947 and 1976, for example, the number of committee staff members employed by the Senate increased from 290 to 1,534. H. FOX, JR. \& S. HAMMOND, supra note 34 , at 171 . The number employed by the House of Representatives rose from 193 to 1,548. Id. In the same period, personal staff employees increased from 590 to 3,251 in the Senate and from 1,440 to 6,939 in the House. Id. The number of staff members working for adjunct legislative entities underwent similar growth. See M. MALBIN, supra note 33, at 257.

47.

In both House and Senate personal offices, six major activity clusters are found: administration, legislative, research, press, correspondence, and oversight. Committee aides' activities in- 


\section{Moreover, recent studies ${ }^{48}$ indicate that congressional staff members} have become increasingly autonomous and self-directed. Because the demands on a typical Member of Congress are formidable, ${ }^{49}$ Members have delegated "enormous authority"so to their aides, without having enough time to supervise its exercise effectively. ${ }^{51}$ Thus, staff members often write speeches that are directly inserted in the Congressional Record, or committee reports that are widely distributed, without these documents having

clude bill drafting, investigation, and dealing with lobbyists. Administrative, research, correspondence, oversight, and some press functions are also performed.

H. FoX, JR., \& S. HAMMOND, supra note 34, at 88. See M. GREEN, Who RUNS CONGRESs? 235 (3d ed. 1979).

48. Prior to 1977, very little research had been done on the activities and impact of congressional staff members. See M. FIORINA, CONGRESS: KEYSTONE OF THE WASHINGTON ESTABLISHMENT 56-57 (1977) ("Sad to say, the subject of the congressional staff is largely a neglected one."); H. FOX, JR. \& S. HAMIMOND, supra note 34, at 5 ("In this array of literature [on Congress], little attention has been given to congressional staffs and no systematic analysis made of their role in the legislative process.") See also E. REDMAN, THE DANCE OF LEGISLATION 18 (1973) ("[T]he best-known academic works on the Senate mention staff only in passing, if at all.") One notable exception was a monograph, $\mathrm{K}$. KOFMEHL, PRofessional STAFFs OF CONGRess (1962), based on research done in the first six years after passage of the Legislative Reorganization Act of 1946, Pub. L. No. 79-601, 60 Stat. 812 (1946) (authorizing hiring, for first time, of permanent professional staff members for congressional committees).

Since 1977, two book-length studies of congressional staffs have appeared. H. FoX, JR. \& S. HAMMOND, supra note 34; M. MALBIN, supra note 33. In addition, the significance of the roles played by congressional aides in the legislative process has been somewhat more widely recognized and discussed in both the general academic literature on Congress, see, e.g., R. JONES \& P. WOLL, THE PRIVATE WORLD OF CONGRESS 127-71 (1979), and the popular press, see, e.g. S. Rich, An Invisible Network of Hill Power, WASHINGTON POST, March 20, 1977, at E1; Cameron, supra note 33, at 38.

49. See OBEY COMMIISSION REPORT, supra note 45, at 10, 17. See also M. GREEN, supra note 47, at 236 (1973 House study found that $38 \%$ of the time Members are scheduled to be in two or more committee meetings simultaneously).

50. M. MAlbin, supra note 33, at 21. See C. ClAPP, THE CONGRESSAMN: HIS WORK AS HE SEES IT 64 (1963); R. RIPLEY, supra note 38, at 213; Cameron, supra note 33, at 39.

51. A House commission found that the typical Representative spends only about 53 minutes in the course of an average day with members of the Representative's personal or committee staffs. OBEY COMIMSSION REPORT, supra note 45 , at 18 ; see D. MATTHEWS, UNITED STATES SENATORS AND THEIR WORLD 85 (1973) ("Even the Senator's own staff members find it 'a real battle to see him," and when they do it is likely to be for so short a period, and in competition with so many other demands on his time. . . .) See also H. FOX, JR. \& S. HAMMOND, supra note 34, at 157, 180 (one result of increasing bureaucratization of congressional staffs is that fewer staff members have day-today contact with Members). Other factors that militate against effective supervision and monitoring of staff activities include the trend toward geographic dispersion of staff members, see M. FIORINA, supra note 48, at 57-58 (increasing proportion of staff members located in state and district offices); H. FOX, JR. \& S. HAMMOND, supra note 34, at 111-12 ("Space is at such a premium that large staffs may be housed in several different locations, in some cases, in as many as four different buildings. Coordination of staff activity and communication is difficult."), and a lack of management experience on the part of many Members, see Huitt, supra note 45, at 114 ("Few Senators are competent (and some not at all, in fact) to operate a small bureaucracy of their own, and that is not their job anyway.")

As a consequence of these various factors, and the sheer volume of work generated in congressional offices, Members of Congress "cannot possibly keep track of all or even most of what goes on in their name." M. MALBIN, supra note 33, at 21; see R. JONES \& P. WOLL, supra note 48, at 144 (describing tendency of Senators with large staffs to "lose control" of those stafis). Staff members have come more and more to operate as "independent professionals." H. FOX, JR. \& S. HAMiOND, supra note 34 , at 3 . 
been read prior to publication by the Members of Congress for whom they were ostensibly prepared..$^{52}$ Aides also have a great deal of discretion in running congressional investigations-in deciding what questions to ask and of whom, what investigatory techniques to use, and what materials to place on the public record..$^{53}$

Staff members are hence in a position to vilify or embarrass those whom they do not like or whose causes they oppose. Their temptation to do so can only be increased if they are given the ability to invoke the protection of the speech or debate clause on their own. Unlike Members of Congress, congressional aides are not accountable to the electorate for activities they engage in under the protection of legislative privilege. ${ }^{54}$

The Court indicated in Gravel that Members of Congress can repudiate, and thereby override, assertions of speech or debate immunity advanced by their aides. ${ }^{55}$ That means, however, that the initial determination as to whether the invocation of immunity is necessary to protect a legislator's independence may be made by a staff assistant, rather than by the legislator-and often in circumstances in which the aide, interested in avoiding legal liability or personal embarrassment, has incentives quite apart from the legislator's independence to seek cover behind the speech or debate clause. This prospect runs counter to the Court's insistence, expressed in other opinions, that the applicability of the clause be confined to circumstances in which it may be presumed that a Member's legislative independence is implicated. ${ }^{56}$ Unless a legislator is willing to affirm that his or her own independence is affected by an inquiry or suit, it seems safe to assume that it is not. To permit any legislative employee to invoke the privilege in the first instance is to expand unnecessarily, and imprudently, what was intended to be a privilege personal to Members of Congress. ${ }^{57}$

The ability of a Member of Congress to veto an aide's assertion of im-

52. See H. FOX, JR. \& S. HAMMIOND, supra note 34, at 145; M. MALBIN, supra note 33, at 143; Cameron, supra note 33 , at $39,42$.

53. See M. MAL.BIN, supra note 33, at 4. While personal, committee, and institutional staff members all do some investigative work, it is notable that the number of investigative staff-that is, temporary staff members hired to work on particular congressional investigations-jumped in the House from 33 in 1947 to 194 in 1960 to 910 in 1975. H. FOX, JR. \& S. HAMMOND, supra note 34, at 24. In the Senate, the number of investigative staff rose from 297 in 1960 to 1124 in 1975. Id; see E. GRIFFITH \& F. VALFO, CON(iRESS: ITS CONTEMPORARY ROLE 97 (1975).

54. For observations related to this point, see R. JONEs \& P. Woll, supra note 48, at 164 (arguing that aides tend over time to become less keenly aware that their power is derivative); M. MALBIN, supra note 33, at 5-6 (expressing concern about exercise of power by unelected aides, and about resultant attenuation of linkage between preferences of electorate and activities of Congress).

55. 408 U.S. at 622 n.13.

56. See, e.g., United States v. Brewster, 408 U.S. 501, 524 (1972).

57. The Court in Gravel acknowledged, in extending speech or debate protection to congressional aides, that the privilege accorded an aide must be viewed "as the privilege of the Senator." 408 U.S. at 621-22. 
munity ${ }^{58}$ cannot be relied upon to prevent abuse or to ensure that the extension of immunity to congressional aides is confined to cases in which the purposes of the speech or debate clause would be furthered. Once an aide has invoked the protection of the clause, a Member may have no compelling interest in revoking the assertion of immunity. Moreover, the Member may in fact have reasons, unrelated to the safeguarding of legislative independence, for not repudiating the aide's claim of privilege. For example, the Member may be unsympathetic to the causes or claims of those bringing suit, or may be concerned about the impact that repudiation of the aide's assertion of privilege might have on the morale or effectiveness of other staff members.

\section{Proposal}

To rectify the problems inherent in the Gravel standard, this Note proposes a new standard: those who assist a Member of Congress in the performance of a legislative function deemed to be within the protection of the speech or debate clause, or who carry out such a function on behalf of a Member, should be entitled to immunity under the clause where (a) that immunity is invoked by the Member, and (b) the Member's motion to dismiss a suit, or to quash a subpoena, includes an affirmation that the aide was in fact acting on the Member's behalf.

The proposed standard differs from the Gravel standard in three crucial respects. First, the proposed rule supplies a clear definition of the universe of persons to whom speech or debate protection may be extended. The suggested definition focuses on an individual's relationship to a specific protected activity, rather than on his or her general, long-term relationship with a Member of Congress. Under this approach to the definition of eligibility, when a Member's legislative independence would be compromised by the questioning of someone who helped the Member on some legislative task, that person could be accorded immunity, and the Member's independence safeguarded, whether or not the person in question was on the Member's payroll or would generally be considered one of the Member's aides.

Second, under the proposed standard, the authority to assert the speech or debate privilege would be confined to those whose independence that privilege was designed to assure: Senators and Representatives. Gravel permits aides themselves to invoke the privilege, subject to the possibility of repudiation by a Member; in effect, this means that whenever an aide seeks to be protected from questioning about some facially legislative act, the presumption is in favor of extending immunity to the aide. The rule

58. See id. at 622 n.13. 
suggested here would reverse this presumption; that is, the presumption would be against the extension of immunity unless and until a member of Congress invoked the speech or debate privilege to bar questioning of the aide.

Third, the proposed rule would require that a Member affirm, in order to protect an aide from questioning, that the aide had been acting on the Member's behalf. That requirement would force the Member to take personal responsibility, formally and publicly, for the aide's activity; thus, a Member is far less likely to assert immunity on an aide's behalf under the proposed standard than he is likely silently to acquiesce in the aide's claim of privilege under the Gravel standard. The resultant shift in the stakes, and therefore the calculus, for Members would affect the expectations and behavior of aides; with a decrease in the likelihood of immunity for acts of dubious propriety, aides would be less likely to risk undertaking such acts. Finally, the required affirmation, by affixing responsibility on the Member, would facilitate recourse to what, in the absence of legal liability, is certainly a venerable alternative remedy for congressional malversations: electoral accountability. 